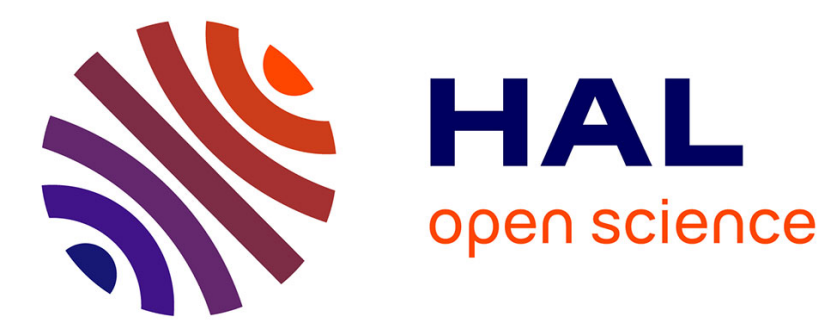

\title{
The age of supergene manganese deposits in Katanga and its implications for the Neogene evolution of the African Great Lakes Region
}

Thierry de Putter, Gilles Ruffet, Johan Yans, Florias Mees

\section{- To cite this version:}

Thierry de Putter, Gilles Ruffet, Johan Yans, Florias Mees. The age of supergene manganese deposits in Katanga and its implications for the Neogene evolution of the African Great Lakes Region. Ore Geology Reviews, 2015, 71, pp.350-362. 10.1016/j.oregeorev.2015.06.015 . insu-01168514

\section{HAL Id: insu-01168514 https://hal-insu.archives-ouvertes.fr/insu-01168514}

Submitted on 26 Jun 2015

HAL is a multi-disciplinary open access archive for the deposit and dissemination of scientific research documents, whether they are published or not. The documents may come from teaching and research institutions in France or abroad, or from public or private research centers.
L'archive ouverte pluridisciplinaire HAL, est destinée au dépôt et à la diffusion de documents scientifiques de niveau recherche, publiés ou non, émanant des établissements d'enseignement et de recherche français ou étrangers, des laboratoires publics ou privés. 
The age of supergene manganese deposits in Katanga and its implications for the Neogene evolution of the African Great Lakes Region

Thierry De Putter ${ }^{1 *}$, Gilles Ruffet ${ }^{2}$, Johan Yans ${ }^{3}$, Florias Mees ${ }^{1}$

${ }^{1}$ Royal Museum for Central Africa, Geodynamics and Mineral Resources, 13 Leuvensesteenweg, B-3080 Tervuren, Belgium

${ }^{2}$ CNRS (CNRS/INSU) UMR 6118, Géosciences Rennes, F-35042 Rennes Cedex, France and Université de Rennes I, Géosciences Rennes, F-35042 Rennes Cedex, France

${ }^{3}$ Université de Namur, Département de Géologie, NaGRIDD, 61 rue de Bruxelles, B-5000 Namur, Belgium

* corresponding author: tel.: $+3227695430,+32478213103$ (mobile); fax: +3227695432 . Email address: thierry.de.putter@africamuseum.be

\begin{abstract}
Supergene manganese deposits commonly contain K-rich Mn oxides with tunnel structure, such as cryptomelane, which are suitable for radiometric dating using the ${ }^{39} \mathrm{Ar}-{ }^{40} \mathrm{Ar}$ method. In Africa, Mn deposits have been dated by this method for localities in western and southern parts of the continent, whereas only some preliminary data are available for Central Africa. Here we present new ${ }^{39} \mathrm{Ar}_{-}{ }^{40} \mathrm{Ar}$ ages for Mn oxide samples of the Kisenge deposit, in southwestern Katanga, Democratic Republic of the Congo. The samples represent supergene Mn oxide deposits that formed at the expense of primary Paleoproterozoic rhodochrositedominated carbonate ores. Main phases of Mn oxide formation are dated at c. 10.5 Ma, 3.6 Ma and 2.6 Ma for a core that crosses a mineralized interval. The latter shows a decrease in age with increasing depth, recording downward penetration of a weathering front. Surface
\end{abstract}


samples of the Kisenge deposits also record a $\geq$ c.19.2 Ma phase, as well as c. 15.7 Ma, 14.2 $\mathrm{Ma}$ and 13.6 Ma phases. The obtained ages correspond to distinct periods of paleosurface development and stability during the Mio-Pliocene in Katanga. Because Katanga is a key area bordered to the North by the Congo Basin and to the East by the East African Rift System, these ages also provide constraints for the geodynamic evolution of the entire region. For the Mio-Pliocene, the Kisenge deposits record ages that are not systematically found elsewhere in Africa, although the 10.5-11 Ma event corresponds to a roughly simultaneous event in the Kalahari Manganese Field, South Africa. The rest of the Katanga paleosurface record differs somewhat from records for other parts of Africa, for which older, Eocene ages have been obtained. This difference is most probably related to the specific regional geodynamic context: uplift of the East African Plateau, with associated erosion, and the opening of the East African Rift System at c. $25 \mathrm{Ma}$ are events whose effects, in the study area, interfere with those of processes responsible for the development of continent-wide paleosurfaces.

Keywords: ${ }^{39} \mathrm{Ar}-{ }^{40} \mathrm{Ar}$ geochronology, cryptomelane, Katanga, Neogene, supergene deposits

\section{Introduction}

Mineral-rich areas in Africa have since long drawn the attention of geologists looking for mineable ore deposits. A typical example of a rich mining area is the Katanga Province, in the south-eastern part of the Democratic Republic of Congo (DRC). From the early $20^{\text {th }}$ century onwards, industrial mining in Katanga has exploited copper, cobalt and uranium, besides other metals such as lead, zinc, and accessory metals associated with the main $\mathrm{Cu}-\mathrm{Co}$ deposits (e.g. germanium). Regional geological studies have for decades focused on the formation of the main primary deposits: Neoproterozoic sediment-hosted stratiform copper 
(SHSC) and cobalt deposits in the Katanga Copperbelt, and the Early Phanerozoic vein-type $\mathrm{Pb}-\mathrm{Zn}-(\mathrm{Ge})$ deposit of Kipushi. However, mining operations also took considerable benefit of the wealth of secondary, oxidized, copper, cobalt and manganese surface deposits in the Katanga Province. Until recently, the formation processes and age of these supergene deposits were poorly constrained. It is now known that these oxidized minerals formed quite recently, in the Neogene (Decrée et al., 2010; De Putter et al., 2010), although older ages have been obtained for other parts of Africa (Table 1).

Supergene deposits form in a geodynamic context that is rather specific. They develop at the expense of primary protores or ores when these are brought to the surface and become exposed, for a sufficient period of time, to the action of meteoric agents. The availability of meteoric fluids is a first order constraint to alter the primary deposit, followed by precipitation of secondary mineral phases, in the form of carbonates, oxides and other compounds. The geodynamic context is thus obviously relevant to understand and characterize how and when the secondary deposits formed. The latter present some significant differences with their primary precursors: (i) paleotopographical context is a major factor to explain their formation and preservation; (ii) fluids involved in their formation are percolating meteoric waters; (iii) the host rock is often modified, becoming either indurated (by silica or iron oxide cementation) or more friable (by weathering), which in the second case results in increased susceptibility to erosion and exposure to oxidizing fluids; and (iv) iron oxides often play a major role in re-concentrating elements of economic value (other than manganese). Another difference with primary ore deposits is that supergene ones are often considerably richer in economic metals, hence having considerable economic interest.

Supergene ore development has been investigated for several major African mining areas (cf. Dill et al., 2013), especially in western and southern Africa (Table 1). In contrast, they have 
been considerably less studied for Central Africa, including Katanga. This paper aims at bridging this gap, by presenting ${ }^{39} \mathrm{Ar}-{ }^{40} \mathrm{Ar}$ results for supergene ore deposits of the Kisenge area in south-western Katanga, where a major secondary Mn oxide accumulation presents an occurrence of suitable materials for absolute age determination.

\section{Setting}

\subsection{Geological and geomorphological context}

The Kisenge area hosts a world-class manganese deposit, occurring in outcrops along an East-West trending $6 \mathrm{~km}$-long series of small hills.

The geological setting of the study area is overall poorly known. The area belongs to the southern part of the Congo Craton, bordering the southern edge of the present-day Congo Basin (Fig. 1). Basement rocks are Archean or Paleoproterozoic (>2.1 Ga) schists, gneiss, migmatites and amphibolites (Ledent et al., 1962; Lepersonne, 1974; Cahen et al., 1984). The primary Mn ore at Kisenge is a rhodochrosite- and spessartine-bearing deposit (ca 50\% $\mathrm{MnO}$ ) interlayered with mudstones and shales, of probable Late Paleoproterozoic age (Schuiling \& Grosemans, 1956; Marchandise, 1958; Doyen, 1974), whose nature is the subject of an ongoing investigation (De Putter and Mees, unpublished data). The best estimate for the age of the Kisenge primary deposit is presently based on the regional geological context and on radiogenic $\mathrm{Rb}$-Sr ages obtained for muscovite in the pegmatite body that crosscuts the deposit. The 1.8-1.9 Ga Rb-Sr age range represents a minimum age estimate for the deposit (Doyen, 1974), which is moreover compatible with ages of similar Paleoproterozoic Mn deposits (cf. Roy, 2006; Kuleshov, 2011). Comparable Mn deposits are known elsewhere in Africa (Burkina Faso, Ghana, Gabon, South Africa), as well as in Brazil, and are all Paleoproterozoic in age (1.9 to 2.2 Ga ; Schneiderhahn et al., 2006; Nyame et al., 2008; 
Chisonga et al., 2012). Some of them, including the Kisenge deposit, are located along the margins of the proto-Congo Craton, which included the Gabon and São Francisco blocks (Fernandez-Alonso et al., 2012).

The Mn carbonate orebody is capped by a thick supergene Mn oxide deposit (Polinard, 1932). This deposit can be considered to be the Mn-dominant equivalent of (Fe-dominant) laterites, which occur extensively in Katanga (Beugnies, 1954; Alexandre, 2002). Alexandre (2002) proposed ages for their multi-stage formation, but this was done exclusively in reference to assumedly equivalent deposits in western Africa (e.g. Tardy and Roquin, 1998). In West Africa, only the Tambao deposit (Burkina Faso) has been extensively studied through ${ }^{39} \mathrm{Ar}^{-}{ }^{40} \mathrm{Ar}$ geochronology (e.g. Hénocque et al., 1998; Colin et al., 2005; Beauvais et al., 2008) and now constitutes a reference system for a regional analysis of Cenozoic paleosurfaces (Beauvais et Chardon, 2013).

Kisenge is situated on a peneplain at $\sim 1,100 \mathrm{~m}$ a.s.1., rising to the east to 1,200 $\mathrm{m}$ around Mutshatsha and >1,500 $\mathrm{m}$ a.s.1. around Kolwezi (Fig. 1), with relict hills culminating some tens of meters above the peneplain level (Polinard, 1932; Doyen, 1974; Alexandre, 2002). The hills marking Mn ore occurrences at Kisenge culminate at $\sim 30$ to $35 \mathrm{~m}$ above the mean peneplain level (Fig. 2). No geomorphological survey has been performed for the Kisenge area, but studies in more eastern parts of Katanga show the presence of various planation surfaces (De Dapper, 1991).

Kisenge is located $\sim 250 \mathrm{~km}$ West of the Katanga Copperbelt, which is part of the Lufilian fold-and-thrust belt (Cailteux et al., 2005; Dewaele et al., 2006; Hitzman et al., 2012).This world-class $\mathrm{Cu}-\mathrm{Co}$ deposit hosts $\sim 50 \%$ of the world's known reserve of mineable cobalt (3.4 Mt Co metal content; USGS, 2009) together with important $\mathrm{Cu}$ deposits. The Katanga 
Copperbelt is also known for its thick derived supergene $\mathrm{Cu}-\mathrm{Co}$ deposits assigned to the MioPliocene based on an earlier preliminary study (Decrée et al., 2010; De Putter et al., 2010).

With its extensive cover of supergene ore deposits, formed on a Paleoproterozoic Mn deposit to the West and on a Neoproterozoic $\mathrm{Cu}$-Co deposit (Copperbelt) to the East, the Katanga province allows precise dating of the development of a major topographic high at the southern margin of the Congo Basin. In a broader context, the geodynamics of the Katanga area during the Cenozoic is probably related to: (i) an overall extensional tectonic regime related to the Mesozoic break-up of Gondwana and opening of the EARS; (ii) long-term erosion and planation of the Lufilian fold belt, and (iii) regional mantle and crust movements associated with the formation of the western branch of the EARS, which started about $25 \mathrm{My}$ ago (Roberts et al., 2012; Kipata et al., 2013; Linol et al, 2015a).

\subsection{Cenozoic regional geodynamic context}

Current knowledge of the Cenozoic uplift history of the Katanga region and surrounding areas, namely the Congo Basin, the Western Branch of the East Africa Rift System (EARS) and the East African Plateau (EAP), can be summarized by reviewing the main documented or inferred events for the Eocene to Pliocene epochs (Fig. 3). Quantitative estimates of landmass/surface uplift changes have been recently published for the Congo Basin (Linol et al., 2015a), but they are still lacking for the study area, south of the Basin.

In the Eocene, between 45 and $35 \mathrm{Ma}$, the EAP experienced major uplift, as a result of buoyancy and melt generation beneath the region (Ebinger et al., 1993; Wichura et al., 2010). During the same period, the Congo basin did not experience significant vertical movement and possibly hosted a large lake at some stage (Peters and O’Brien, 1999; Lavier et al., 2001; Goudie, 2005; Guillocheau et al., 2015). 
In the Oligocene, from around 25 Ma onward, both branches of the EARS opened (Pik et al., 2008; Roberts et al., 2012). Around the same time, uplift of the Angolan High and the Congo Basin resulted in a sharp increase in sedimentation rates offshore in the Congo fan (Lavier et al., 2001; Anka et al., 2009 and 2010).

In the early to middle Miocene (c. 17-12 Ma; Wichura et al., 2010), the EAP experienced another major uplift. To the West, the Congo Basin had a similar evolution somewhat later (Lavier et al., 2001; Anka et al., 2009, 2010).

For the middle to late Miocene, a stable tectonic setting is recorded for the EAP, which allowed the development of an abundant and stable tree cover in the c. 10 to 8 Ma interval (Bonnefille, 2010). In the Congo Basin, uplift rates increased sharply after $11 \mathrm{Ma}$ (Lavier et al., 2001; Anka et al., 2009, 2010). Stable isotope studies on fossil eggshells suggest that the entire Congo Basin area experienced an arid climate during the middle to upper Miocene (Senut et al., 2009).

In the late Miocene (c. 7.5 Ma), major rifting took place in the Western branch of the EARS (Pasteels et al., 1989), with associated culmination of volcanic activity. The uplift rate of the Congo basin reached a maximum in the c. 11 to 5 Ma interval (Lavier et al., 2001; Guillocheau et al, 2015).

In the Pliocene, the EAP still experienced uplift while to the west the uplift rate of the Congo Basin sharply decreased (Lavier et al., 2001).

In the course of this Cenozoic history, and even since the end of the Pan-African orogeny (c. $450 \mathrm{Ma})$, the Eastern part of Katanga Plateau was apparently never covered by a thick sediment cover. Mesozoic sediments in particular are lacking, in contrast to the thick sequences deposited in the adjoining Congo Basin. Cenozoic deposits (Kalahari Series) occur 
only sporadically in the Copperbelt area, but they become more continuous and thicker toward the West, in the western DRC and Angola (Linol et al., 2015b).

During the Cenozoic, the Katanga Plateau occupied a stable position between two major morphotectonic zones: the Congo Basin to the North and Northwest and the EARS to the East and Northeast. This stability allowed the formation of an extensive lateritic cover on the southern Katanga Plateau, as described by Alexandre (2002). The latter recognized four types of laterites in the region, each attributed to a different period (Early Eocene, EoceneOligocene, Miocene, Pliocene). However, no absolute age information was available to the author in support of this proposed chronology.

\section{Materials}

\subsection{Analysed mineral phase}

The most suitable Mn oxide mineral for ${ }^{39} \mathrm{Ar}-{ }^{40} \mathrm{Ar}$ study is cryptomelane $\left(\mathrm{K}\left(\mathrm{Mn}^{4+}{ }_{7} \mathrm{Mn}^{3+}\right) \mathrm{O}_{16}\right)$, which is the K-rich ( $>5 \%$ ) end-member of a group of Mn oxides with tunnel structure (coronadite group, hollandite supergroup) with $\mathrm{A}^{2+}\left[\mathrm{M}^{4+}{ }_{6} \mathrm{M}^{3+}{ }_{2}\right] \mathrm{O}_{16}$ or $\mathrm{A}^{+}\left[\mathrm{M}^{4+}{ }_{7} \mathrm{M}^{3+}\right] \mathrm{O}_{16}$ as general formula, with $\mathrm{A}=\mathrm{K}, \mathrm{Na}, \mathrm{Pb}, \mathrm{Ba}, \mathrm{Sr}$, and $\mathrm{M}^{3+}$ and $\mathrm{M}^{4+}=\mathrm{Mn}$ (Biagioni et al., 2013). These Mn oxides can have a composition that is intermediate between that of the endmembers of this group, resulting in variable $\mathrm{K}$ contents, also at the scale of aliquots used for ${ }^{39} \mathrm{Ar}-{ }^{40} \mathrm{Ar}$ study. Moreover, other manganese oxide minerals may be present within analysed grains, such as pyrolusite $\left(\mathrm{MnO}_{2}\right)$ and lithiophorite $\left((\mathrm{Al}, \mathrm{Li})\left(\mathrm{Mn}^{4+}, \mathrm{Mn}^{3+}\right)_{2} \mathrm{O}_{2}(\mathrm{OH})_{2}\right)$, as confirmed by SEM-EDS and XRD analysis for sample Kis-1/36 (Fig. 4).

All minerals of the coronadite group are suitable for $\mathrm{K}-\mathrm{Ar}$ and ${ }^{39} \mathrm{Ar}^{40}{ }^{40} \mathrm{Ar}$ geochronological investigations, if they contain some structural $\mathrm{K}$, because they have a tunnel structure which ensures retentiveness of argon (Vasconcelos et al., 1992, 1994, 1995; Lippolt and Hautmann, 
1995). In the majority of ${ }^{39} \mathrm{Ar}-{ }^{40} \mathrm{Ar}$ or K-Ar studies of Mn oxides, cryptomelane refers to $\mathrm{Mn}$ oxide materials which contain some $\mathrm{K}$, even if other cations are dominant.

Mn oxides commonly used in ${ }^{39} \mathrm{Ar}-{ }^{40} \mathrm{Ar}$ studies are compact fine-grained aggregates of needle-shaped crystals (e.g. Vasconcelos et al., 1994; Ruffet et al., 1996). These aggregates, which are commonly laminated at macro- to microscopic scales (e.g. RGM 13933 and Kis1/36 in Figure 4), record successive stages of mineral deposition by accretion or transformation (dissolution/reprecipitation), representing a range of equilibrium/disequilibrium conditions. Development of a laminar structure is controlled by changes in fluid composition in terms of element availability and mobility, notably for potassium (cryptomelane formation) or aluminum (lithiophorite formation), resulting in $\mathrm{K}$ content variations between laminae (Fig. 4). K content variability can also be related to multiple interactions taking place between Mn oxides and fluids that enter the system after initial deposition, resulting in deposits recording different phases of mineralization. As a result, aggregates form over millions of years (1 to $5 \mathrm{~mm} / \mathrm{Ma}$ for laminated concretions, Hénocque et al., 1998), and they appear to be more complex if they crystallized early during the evolution of this system.

\subsection{Analysed samples}

From historical drilling campaigns (Doyen, 1974), the secondary Mn ore is known to extend down to $\sim 100 \mathrm{~m}$ below the peneplain surface, i.e. down to $\sim 1,000 \mathrm{~m}$ a.s.l. (Fig. 2). It occurs as east-west trending subvertical beds dipping south, consisting of black massive manganese oxides, derived from sedimentary layers with favourable lithological characteristics. Surface occurrences are apparently always related to outcrops of these subvertical Mn-rich beds, with in-situ Mn-oxide deposition. Occasional occurrences of thin manganese oxide veins are noted at lower depth. 
Manganese oxides in the Kisenge area deposits partly occur as impregnative material, in a matrix derived from the garnet-bearing rhodochrosite-dominated rocks and graphitic shales that constitute the primary ore deposits and intervening barren layers. In addition, the oxides also occur abundantly as void-filling phases, ranging from thin massive veins to thick laminar crusts.

Fifteen K-rich Mn oxides samples from the Kisenge deposits were selected from the mineral and core collections of the Royal Museum for Central Africa (RMCA). The selected specimens are part of several series of samples of the Kisenge deposits that were collected mainly between 1945 to 1965 , around the time when exploitation started (1951; Doyen, 1974). All samples used for ${ }^{39} \mathrm{Ar}-{ }^{40} \mathrm{Ar}$ geochronology are K-rich, with a composition close to that of the cryptomelane K-end member of the coronadite group.

Five samples were taken from the Kis-1 oblique core (Figs 2, 5; Table 2), which crosses Mn oxide intervals at depth, mostly from -50 to $-70 \mathrm{~m}$ (along core) and perhaps less continuously between -80 and $-90 \mathrm{~m}$. Below $-90 \mathrm{~m}$ the sediments in the core are dominated by barren shale, with one 3 m-thick intercalation of unaltered Mn-carbonate (rhodochrosite) deposits ($130 \mathrm{~m}$ ), overlying a 4m-thick interval with abundant Mn-rich garnet (spessartine). Samples were taken from the main -50 to $-70 \mathrm{~m}$ interval (Fig. 2), where several cryptomelane-rich subsamples could be isolated for ${ }^{39} \mathrm{Ar}^{-}{ }^{40} \mathrm{Ar}$ age determination. One sample (Kis-1/30) represents a Mn-oxide vein crossing the deposits above the -50 to $-70 \mathrm{~m}$ interval, at $-46 \mathrm{~m}$ depth.

All other analysed specimens are surface samples (Table 2; Fig. 5), again meeting the requirement of high $\mathrm{K}$ content (checked by SEM-EDS).

Although the mineralogical homogeneity of the samples is unambiguously confirmed by XRD analysis, physical heterogeneities are observed, mostly expressed as lamination (Figs. 
$4,7)$. The origin of lamination is not precisely known: it has been noted also for malachite (De Putter et al., 2010) and might result, for both minerals, from variations in chemical composition and/or fabric between laminae (Mees et al., 2012). Occasional accompanying minerals detected for the analysed features are lithiophorite (Kis-1/36, Kis-1/53, RGM 14296) and quartz (Kis-1/36, Kis-1/62). Traces of mica were only detected for RGM 17006, which yields a non-interpretable ${ }^{39} \mathrm{Ar}-{ }^{40} \mathrm{Ar}$ age spectrum (see further).

\section{Methods}

The mineralogical composition of the specimens was determined by X-ray diffraction analysis, with a Philips diffractometer (PW3710), using $\mathrm{CuK} \alpha$ radiation $(40 \mathrm{kV}, 30 \mathrm{~mA})$ and a scanning speed of $2.5 \mathrm{~s}$ per $0.02^{\circ} 2 \theta$. All samples were screened using a JEOL 7500-F scanning electron microscope at $15 \mathrm{kV}$ (UNamur, Belgium).

The samples for ${ }^{39} \mathrm{Ar}-{ }^{40} \mathrm{Ar}$ age determination were wrapped in $\mathrm{Al}$ foil to form small packets $(11 \times 11 \mathrm{~mm})$ that were stacked to form columns within which fluence monitors were inserted every 10 samples. Two distinct irradiations were performed at the McMaster reactor (Hamilton, Canada). The first irradiation (samples KIS 1-30, KIS 1-58, RGM1769, RGM13200 and RGM13201) used the 5C high flux location without Cd-shielding and lasted $16.667 \mathrm{hr}\left(\mathrm{J} / \mathrm{h} \approx 3.5 \times 10^{-4} \mathrm{~h}^{-1}\right)$. The second irradiation which concerned all other samples (including a second set of grains from sample RGM 13201) used a medium flux location (8E) with Cd-shielding and lasted $52 \mathrm{hr}\left(\mathrm{J} / \mathrm{h} \approx 4.4 \times 10^{-5} \mathrm{~h}^{-1}\right)$. In both cases irradiation standard was sanidine TCRs $(28.608 \pm 0.033 \mathrm{Ma}$; Renne et al., 1998, 2010, 2011). Sample arrangement during irradiation allowed monitoring of the flux gradient with a precision of $\pm 0.2 \%$.

Heating steps were performed with a $\mathrm{CO}_{2} \operatorname{Synrad}^{\circledR}$ laser (Ruffet et al., 1991, 1995). The five argon isotopes and the background baselines were measured in eleven cycles, in peak- 
jumping mode. Blanks were performed routinely each first or third/fourth run, and subtracted from subsequent sample gas fractions. All isotopic measurements are corrected for $\mathrm{K}, \mathrm{Ca}$ and $\mathrm{Cl}$ isotopic interferences, mass discrimination and atmospheric argon contamination.

Apparent age errors are plotted at the $1 \sigma$ level and do not include errors on ${ }^{40} \mathrm{Ar}^{*} /{ }^{39} \mathrm{Ar}_{\mathrm{K}}$ ratio, monitor age and decay constant. The latter are included in the final calculation of the (pseudo-)plateau age error margins or for apparent ages individually cited. Analyses were performed on a Map215 ${ }^{\circledR}$ mass spectrometer.

It is commonly considered that a plateau is obtained when calculated ${ }^{40} \mathrm{Ar}^{*} /{ }^{39} \mathrm{Ar}_{\mathrm{K}}$ ratios of at least three consecutive steps, comprising a minimum of $70 \%$ of the ${ }^{39} \mathrm{Ar}$ released, agree within $1 \sigma$ or $2 \sigma$ error bars with the weighted mean calculated ${ }^{40} \mathrm{Ar}^{*} /{ }^{39} \mathrm{Ar}_{\mathrm{K}}$ ratio of the plateau segment. Pseudo-plateau ages (PPA) can be defined with less than $70 \%$ of the ${ }^{39}$ Ar released. All ages are reported at the $1 \sigma$ level.

Analytical data and parameters used for calculations (e.g. isotopic ratios measured on $\mathrm{K}, \mathrm{Ca}$ and $\mathrm{Cl}$ pure salts; mass discrimination; atmospheric argon ratios; $\mathrm{J}$ parameter; decay constants) and reference sources are available in supplementary data repository.

\section{Results}

\subsection{Age spectra characteristics}

As frequently observed during ${ }^{39} \mathrm{Ar}-{ }^{40} \mathrm{Ar}$ geochronological studies of weathering profiles, only the youngest samples, less likely to be affected by multiple crystallization events, yield simple results characterized by flat age spectra allowing unambiguous plateau age calculation (Fig. 6). This is illustrated by one of the lowest samples of the Kis-1 core (sample Kis-1/58), with a flat age spectrum which yields a calculated plateau age of $3.6 \pm 0.2 \mathrm{Ma}$. For this 
sample, the c. $2.3 \mathrm{Ma}$ age reported by Decrée et al. (2010) was recalculated at c. $3.6 \mathrm{Ma}$, using updated decay constants and atmospheric argon ratios. This age is corroborated by a plateau age of $3.6 \pm 0.1$ Ma yielded by surface sample RGM 1769. The youngest age obtained by the present study is a plateau age of $2.6 \pm 0.2$ Ma calculated for the age spectrum of the RGM 13200 surface sample.

However, even sample Kis-1/62, the lowest analysed Kis-1 core sample, displays a 'disturbed' age spectrum, resulting from mixing of the two components previously identified (c. 2.6 and $3.6 \mathrm{Ma}$ ).

Most other analysed cryptomelane-rich samples are probably composite aggregates of $\mathrm{Mn}$ oxides with distinct K contents which crystallized at different stages. Some components of these analysed materials may have low $\mathrm{K}$ contents and the conventional age spectrum poorly accounts for this, as it uses the percentage of total ${ }^{39} \mathrm{Ar}_{\mathrm{K}}$ (\# to K) degassed as discriminating parameter, which is not weighted by temperature (or laser power) increment. In this case, some alternative or supplementary types of representation or calculation can be used, such as (i) correlation $\left({ }^{36} \mathrm{Ar} /{ }^{40} \mathrm{Ar}\right.$ vs. ${ }^{39} \mathrm{Ar}_{\mathrm{K}} /{ }^{40} \mathrm{Ar} *$ inverse isochron; Turner, 1971; Roddick et al., 1980; Hanes et al., 1985); (ii) pseudo-plateau age (PPA) calculations, i.e. plateau age calculated with less than $70 \%$ of the ${ }^{39} \mathrm{Ar}_{\mathrm{K}}$ released; (iii) degassing analysis, i.e. visualization of degassing peak $(\mathrm{s})\left(\left({ }^{\mathrm{x}} \mathrm{Ar} / \Delta \mathrm{T}^{\circ}\right) /\left({ }^{\mathrm{x}} \mathrm{Ar} / \Delta \mathrm{T}^{\circ}\right)_{\text {Max }}\right.$ versus $\%{ }^{39} \mathrm{Ar}_{\mathrm{K}}$, with $\mathrm{x}=36$ to 40$)$ or the use of weighted age spectra (apparent ages versus $\left.\%\left({ }^{39} \mathrm{Ar}_{\mathrm{K}} / \Delta \mathrm{T}^{\circ}\right) /\left({ }^{39} \mathrm{Ar}_{\mathrm{K}} / \Delta \mathrm{T}^{\circ}\right)_{\mathrm{Max}}\right)$.

The usefulness of such alternative procedures can be illustrated for the results obtained for sample RGM 10727c (Fig. 7). The staircase shape of the conventional age spectrum (Fig. 7C) suggests that the analysed material was composite. The regular shape of the spectrum could be explained by mixing of only two distinct phases, whereby a maximum age for the youngest phase $(\gamma)$ would be estimated from low-temperature apparent ages, with a PPA of 
c. 10.8 Ma, whereas a minimum age estimate for the oldest phase $(\alpha)$ would be suggested by high temperature apparent ages, with a PPA of c. 14.2 Ma. In fact, a detailed analysis of the data shows that there are at least three distinct phases within the analysed grain. The degassing diagrams $\left({ }^{40} \mathrm{Ar} *\right.$ and ${ }^{36} \mathrm{Ar}$, Fig. 7A $)$ display a peak in the low to intermediate temperature steps, with a maximum at c. $15 \%$ of ${ }^{39} \mathrm{Ar}_{\mathrm{K}}$ degassing, which irrefutably evidences a 'hidden' phase $(\beta)$, poorly expressed in the conventional age spectrum (PPA $13.6 \pm 0.1 \mathrm{Ma}$ ) but magnified when taking into account degassing intensity of ${ }^{39} \mathrm{Ar}_{\mathrm{K}}$ $\left(\%\left[{ }^{39} \mathrm{Ar}_{\mathrm{K}} / \Delta \mathrm{T}^{\circ}\right]\right)$ (Fig. 7D). This alternative representation of apparent ages clearly shows two successive staircase segments (I and II, Fig. 7D), which express transitions between the three distinct phases constituting the analysed grain. The existence of these three distinct phases is furthermore confirmed by inverse isochron analysis (Fig. 7B), which yields three distinct isochrons resulting from mixing between an atmospheric reservoir, attested by three concordant $\left({ }^{40} \mathrm{Ar} /{ }^{36} \mathrm{Ar}\right)_{\mathrm{i}}$ atmospheric ratios, and three distinct radiogenic components. These isochrons are joined by transition steps (I and II, Fig. 7D), which are the counterparts of the age spectra PPA connections (Fig. 7C,D). Obviously, isochron ages are fully concordant with calculated pseudo-plateau ages.

The youngest phase $(\gamma, 10.8 \pm 0.2 \mathrm{Ma})$ is weakly expressed in the conventional and alternative age spectra (Fig. 7C,D), either as a result of its low total volume within the analysed grain or more probably because of its low $\mathrm{K}$ content. Nevertheless, its imprint is strong in the inverse isochron diagram (Fig. 7B), due to its related high atmospheric contamination (93.4\% to $68.1 \%$ ) with a clearly defined and specific ${ }^{36} \mathrm{Ar}_{\text {atm }}$ degassing peak (Fig. 7A), and its existence is established with certainty.

A striking feature of sample RGM 10727c is the progressiveness of degassing of the distinct phases $(\gamma \rightarrow \beta \rightarrow \alpha)$ constituting the analysed composite grain, from youngest to oldest. It 
could be argued that this feature is linked to heterogeneity of the analysed material (Fig. 7E), degassing first the laminated cover deposit, corresponding to the youngest phase $(\gamma)$, and then the rounded aggregates of the covered substrate, corresponding to the older phases $(\beta \rightarrow \alpha)$. Nevertheless, because all identified phases were simultaneously exposed to the laser beam during step-heating (see picture in Figure 7E, taken before the grain fusion step, with surface exposed to laser beam perpendicular to lamination in cross-section), the spreading of degassing peaks must be related to differences in ${ }^{40} \mathrm{Ar}$ * retentiveness, whereby values decrease as younger phases are formed $(\alpha \rightarrow \beta \rightarrow \gamma)$. This could be attributed to differences in crystal structure properties. The retentiveness variability of successive crystallized phases could be controlled by $\mathrm{K}$ availability, which generally decreases with the lowering of the weathering front; alternatively, it could also change through progressive increase in crystallinity, with 'ageing' of the deposits.

Most of the experiments performed on samples from this study evidence younger superimposed phases in the low to intermediate ${ }^{39} \mathrm{Ar}_{\mathrm{K}}$ degassing domain which usually can be characterized through PPA and inverse isochron calculations. On the other hand, preservation of the older main phase depends on the sequential occurrence of degassing of the various $\mathrm{Mn}$ oxides generations. Degassing of the younger generation can overlap with or be superimposed on that of the older main generation. Such configurations generate fully staircase-shaped age spectra, without flat segments in the high temperature domain of the spectra (e.g. RGM 10739 and 14296, Fig. 6), or hump-shaped patterns (Kis-1/30, 1/36 and 1/53, RGM 1767c and 10724, Fig. 6). The highest apparent age reached in a staircase-shaped age spectrum would be a minimum estimate of the age of the main phase. Similar conclusions could be drawn for hump-shaped age spectra but these are more delicate to interpret. 


\section{2. ${ }^{39} \mathrm{Ar}-{ }^{40} \mathrm{Ar}$ ages}

In view of the preceding discussion, the oldest age obtained in this study $(19.2 \pm 0.1 \mathrm{Ma}$, RGM 1767c) is probably a minimum estimate for the age of the oldest phase, which is probably also the case for the age of $17.6 \pm 0.1$ Ma obtained for sample RGM 10724. On the other hand, the age of $10.5 \pm 0.1$ Ma yielded by sample Kis-1/30 (Fig. 6) is probably the best estimate for the age of the oldest phase recorded by core Kis-1, coherent with its position in the weathering profile (Fig. 2). A c. 10.5 Ma phase is recurrently observed for other samples, either as remnants of a 'main' phase $(10.5 \pm 0.1$ Ma for RGM 10739, Fig. 6), or as a lowtemperature superimposed phase $(10.8 \pm 0.2 \mathrm{Ma}$ for RGM 10727c, $10.6 \pm 0.4 \mathrm{Ma}$ for RGM 13933). It is also clearly evidenced through isochrones analyses, yielding 10.8 $\pm 0.3 \mathrm{Ma}$ for RGM 10727c (Fig. 7B) and 10.7 \pm 1.1 Ma for RGM 13933 (Fig. 6). Similarly, a c. 2.6 Ma episode is clearly recognized for the weathering sequence. As previously discussed, it is observed as a main component (RGM 13200, with the best plateau obtained during this study at $2.6 \pm 0.2 \mathrm{Ma}$; Fig. 6), but also as a low-temperature superimposed phase, both in the core (Kis-1/62, $2.7 \pm 0.2 \mathrm{Ma}$ ) and in surface samples (RGM 14296, $2.6 \pm 0.2 \mathrm{Ma}$ ). The 2.6 Ma phase is relatively poorly expressed in the age spectra, but it is more apparent through isochron analysis (2.7 \pm 0.3 Ma for Kis-1/62, $2.6 \pm 0.4$ Ma for RGM 14296; Fig. 8).

Surface samples yield a broader age range than the core samples, with an oldest phase of at least c. 19.2 Ma and a youngest phase of c. 2.6 Ma. The three main components identified for core Kis-1 (10.5 Ma; 3.6 Ma; 2.6 Ma) can also be observed for these samples as main and superimposed phases.

As expected, the older phases are the least well expressed (e.g. Vasconcelos and Conroy, 2003). An $\geq 19.2 \pm 0.1$ Ma age is certainly recorded for sample RGM 1767c and possibly for RGM 10724. On the other hand, a c. 15.7 Ma phase is rather well preserved, as it is observed as a main component for samples RGM 13933 (15.7 \pm 0.1 Ma) and possibly RGM 14296 
$(>15.0 \pm 0.1 \mathrm{Ma})$, and also as one of both superimposed components for sample RGM 1767c $(15.9 \pm 0.1 \mathrm{Ma})$. In the same way, a parallel could be drawn between the c. $14.2 \mathrm{Ma}$ component derived from the previously presented analysis for sample RGM 10727c, and the lowest-temperature subordinate c. 14.9 Ma component observed for sample RGM 1767c.

Finally, a weakly expressed c. 13.6 Ma phase, detected as a superimposed component for sample RGM 10727c (see above) is also discernible as a low-temperature component through isochron analysis for sample RGM 10724 but never as main phase. Any attempt to identify others phases would be highly speculative because the available data do not allow crosschecking within those other parts of the age range.

In summary, three main phases are recognized both for the Kis-1 core and for surface samples, corresponding to c. $10.5 \mathrm{Ma}, 3.6 \mathrm{Ma}$ and $2.6 \mathrm{Ma}$. In addition, analyses of surface samples show that cryptomelane also formed before c. $19.2 \mathrm{Ma}$ and sporadically during at least three periods in the course of the middle Miocene, at c. 15.7 Ma, c. 14.2 Ma and c. 13.6 Ma., before the c. 10.5 Ma main phase.

\section{Discussion}

\subsection{Significance of the obtained ages}

${ }^{39} \mathrm{Ar}-{ }^{40} \mathrm{Ar}$ dating results obtained for the Kisenge Mn oxide deposits suggest that the area occupied an overall stable position across the Mio-Pliocene time interval (c. 20 to c. $2.5 \mathrm{Ma}$ ). The results are marked by a lack of Paleocene or Eocene ages, which have been widely recorded for similar paleosurface-related deposits occurring in other parts of Africa and in South America (Vasconcelos et al., 1994; Ruffet et al., 1996). Scattered but widespread occurrences of bauxite throughout the DR Congo have been attributed to a major Paleogene lateritization episode that affected the whole of Central Africa (Guillocheau et al., 2015), as also recorded for West Africa (Tardy et al., 1991; Chardon et al., 2006; Burke \& Gunnell, 
2008; Butt and Bristow, 2012). The present study indicates that, in Central Africa, these deposits have subsequently been eroded, most likely during the first major uplift stage of the East African Plateau (Dome), during the Eocene-Oligocene (Ebinger et al., 1993; Wichura et al., 2010), leaving no traces of this major, possibly continent-wide, lateritization event in the Katanga plateau area.

The oldest recorded ages for the Kisenge deposits ( $\geq$ 19.2 Ma, 15.7 Ma, 14.2 Ma, 13.6 Ma) do not correspond with any known periods of regional low tectonic activity which would have favoured landscape stability and duricrust development. A next and major phase of Mn oxide formation (10.5-11 Ma) roughly coincides with a period of EAP stability during the middle to upper Miocene. No significant events are subsequently recorded for the upper Miocene, when active rifting took place in the East and high uplift rates were attained in the Congo Basin. Uplift rates for this region were much lower during the Pliocene, a period marked at Kisenge by well-expressed Mn oxide occurrences, around 3.6 Ma and 2.6 Ma. The latter roughly coincides with start of the Pleistocene aridity in the EARS and EAP areas (Goudie, 2005; Gasse, 2006; Bonnefille, 2010). This appears to be mainly significant in terms of a lack of more recent recorded stages of Mn oxide accumulation, as the preceding upper Miocene to Pliocene wetter phase (Senut et al., 2009) may have presented more favourable conditions. Secondary ore deposition in humid conditions in Katanga is suggested by the rather common occurrence of malachite in the form of stalactitic speleothems (Decrée et al., 2010; De Putter et al., 2010), a morphology that is also known for Mn oxide deposits from Kisenge (RMCA collection). The preservation of the 2.6 Ma deposit also implies that they were not entirely removed by erosion following their formation, despite Quaternary landscape evolution (De Dapper, 1991).

Overall, the Miocene and Pliocene weathering events identified in this study fit fairly well with periods of laterite formation recognized for the African continent (Hénocque et al., 
1998; van Niekerk et al., 1999; Colin et al., 2005; Boni et al., 2007; Beauvais et al., 2008; Decrée et al., 2010; Gutzmer et al., 2012 ).

\subsection{Implications for paleosurface evolution}

The uplift rate computed for the Congo basin based on sediment discharge data for the offshore Congo fan amounts to $\sim 5 \mathrm{~m} / \mathrm{My}$ within the 11-5 Ma time interval. In the 5-0 Ma interval, the uplift slowed down to the West of the study area (Congo basin) but it increased to the East, in the EAP area (Fig. 3; Lavier et al., 2001; Guillocheau et al., 2015).

The three phases dated at c. 10.5 Ma, 3.6 Ma and 2.6 Ma by the ${ }^{39} \mathrm{Ar}^{-}{ }^{40} \mathrm{Ar}$ study of the Kis-1 core samples are major episodes in the weathering history of the area (Fig. 9). The $10.5 \mathrm{Ma}$ event follows several older ones (>19.2 to $13.6 \mathrm{Ma})$. During the $10.5 \mathrm{Ma}$ stage, the weathering front descended to $1034 \mathrm{~m}$ a.s.l., below a surface level whose exact elevation at the time is not known. This was followed by a c. 6.9 Myr quiescent period. At c. 3.6 Ma, new meteoric fluid input affected the whole preexisting weathering column and allows a next phase of weathering front lowering, down to $1026 \mathrm{~m}$ a.s.l. For the subsequent phase, at c. 2.6 Ma, there is no evidence for further lowering of the weathering front. Minor (undated) Mn oxide occurrences are however observed at $\sim 1015 \mathrm{~m}$ a.s.1., and the unweathered Mncarbonate ore is cut at $\sim 980 \mathrm{~m}$ a.s.l. (Figs 2, 9). The ${ }^{39} \mathrm{Ar}-{ }^{40} \mathrm{Ar}$ dating results for the Kis-1 core samples, taken at known depth and present-day absolute altitude, show that a total thickness of $\geq 100 \mathrm{~m}$ (1130-1026 $\mathrm{m}$ a.s.l.) has been affected by the downward penetration of the weathering front, over a 6.9 My period (from 10.5 to 3.6 Ma) (Figs 2, 9). This figure has to be considered with caution, as the downward penetration of the weathering front might be irregular in time and space, and will vary with host-rock permeability and porosity. 
Similar features were recognized for the manganese ore deposit of Tambao in northern Burkina Faso with more limited thickness (c. 70-80 m) of the main Mn-oxide bodies, and occasional occurrences of manganese oxide veins down to c. $110 \mathrm{~m}$ beneath hilltop level (Beauvais et al. 2008). Detailed correlations between ${ }^{39} \mathrm{Ar}-{ }^{40} \mathrm{Ar}$ cryptomelane ages and geomorphologic features have been performed in the Tambao area, where five Cenozoic paleosurfaces have been recognized and dated (Beauvais et al., 2008). They were subsequently used as a basis for a regional analysis for West Africa (Beauvais and Chardon, 2013). Such precise correlations are not yet possible for the Kisenge area where critical information regarding denudation rates, uplift rates, and recent tectonic history are lacking. Paleosurfaces were however recognized to the East, in the Copperbelt (De Dapper, 1991), and some might be derived from a DEM for the study area (Fig. 9), but it seems premature to equate them with the ${ }^{39} \mathrm{Ar}-{ }^{40} \mathrm{Ar}$ cryptomelane ages obtained in the Kis-1 core.

The thickness of the weathering zone at Kisenge ( $\geq 100 \mathrm{~m}$, formed over $\sim 7$ My) seems small when compared to the western part of the Copperbelt, where the substrate is weathered down to $\sim 300$ meters below the surface (Dewaele et al., 2006). Deeper weathering in the Copperbelt was probably favoured by the calcareous facies that hosts the $\mathrm{Cu}-\mathrm{Co}$ mineralization (De Putter et al., 2010). By contrast, the rhodochrosite ore of Kisenge is interlayered within siliciclastic sediments (shale), less prone to dissolution and the formation of caves and other karstic cavities. The $15 \mathrm{~m} / \mathrm{My}$ rate in Kisenge is however significantly higher than the $\sim 4 \mathrm{~m} / \mathrm{My}$ value calculated for poorly developed weathering profiles in tectonically quiescent zones in the Proterozoic Mount Isa Block in Northern Australia (Vasconcelos and Conroy, 2003). The difference between the two rates may be seen as a further indication that the study area was (and still is) a tectonically active zone in the period considered in this study (Kipata et al., 2013), with discrete quiescent phases allowing the formation of Mn oxides. 


\subsection{Comparison with other African supergene deposits}

Radiometric ages for supergene manganese deposits have been published for several parts of Africa, which can be grouped as West Africa and southern Africa (Table 1). Palaeocene ages were only obtained for West Africa (Colin et al., 2005; Beauvais et al., 2008) whereas Eocene ages are recorded for both West and southern Africa (Hénocque et al., 1998; Colin et al., 2005; Beauvais et al., 2008; Gutzmer et al., 2012). As mentioned above, any possible occurrences of these generations of duricrusts in Kisenge have been eroded during a major Eocene-Oligocene uplift stage.

The pre-19 Ma phase that is tentatively recognized for Kisenge may correspond to the Oligocene phase (c. $25 \mathrm{Ma}$ ) that is documented for West Africa (Colin et al., 2005; Beauvais et al., 2008) and southern Africa (Boni et al., 2007; Gutzmer et al., 2012).

For the Mio-Pliocene, the Kisenge deposits record ages that are not systematically found elsewhere in Africa. The 10.5-11 Ma event only corresponds to a roughly simultaneous event in the Kalahari Manganese Field, South Africa (Gutzmer et al., 2012). This correspondence suggests that the relative stable tectonic setting experienced in the Katanga area extended far southward at that stage. A common evolution of both areas in the Neogene is further demonstrated by the deposition of a sandy sedimentary cover, as part of the so-called 'Kalahari Group', on a vast area stretching from the southern margin of the Congo Basin (including Katanga) to the Kalahari area in southern Africa (Linol et al., 2015b).

The rest of the Katanga paleosurface record differs from records for other parts of Africa. The interpretation of this difference is not straightforward, in view of possible sampling bias, the lack of regional geomorphological studies and the likely influence of Oligocene EARS opening. 
From the beginning of the Paleogene, the geodynamic history of the region is largely controlled by the evolution of the neighbouring Eastern African Plateau. Uplift, erosion, and the opening of the EARS at c. 25 Ma are clearly events whose effects outweigh those of processes responsible for the development of continent-wide paleosurfaces. This major tectonic forcing has even had a strong impact on continental ocean-atmosphere circulation, and hence on the climate and precipitation regimes prevailing in Central Africa (Prömmel et al., 2013).

\section{Conclusion}

The ${ }^{39} \mathrm{Ar}-{ }^{40} \mathrm{Ar}$ geochronological study of cryptomelane of the Kisenge manganese deposit provides information on the Mio-Pliocene evolution of an area that is located South of the Congo Basin and West of the EARS. Discrete phases of cryptomelane formation are dated at c. 10.5 Ma, 3.6 Ma and 2.6 Ma for an interval crossed by the Kis-1 core. Dating of core samples dating also suggests that a total thickness of $\geq 100 \mathrm{~m}$ has been affected by the downward penetration of the weathering front, over a 6.9 My period (from 10.5 to 3.6 Ma). This value seems low when compared to the total thickness of weathered sediments in the Copperbelt which at least locally sometimes exceeds $300 \mathrm{~m}$. The difference may be due to the abundance of calcareous host rocks in the Copperbelt area, susceptible to dissolution (De Putter et al., 2010).

In addition to the $<10.5 \mathrm{Ma}$ ages obtained for the Kis-1 core, surface samples from the Kisenge area also record $\mathrm{a} \geq$ c. 19.2 Ma phase, as well as c. 15.7 Ma, 14.2 Ma and 13.6 Ma phases. The absence of Eocene and Oligocene ages at Kisenge most probably results from the removal of corresponding generations of duricrusts during major Paleogene uplift stages. As a result, the Paleogene evolution of the study area cannot be compared with that of other parts 
of Africa for which supergene manganese deposits have been studied (Table 1), and a series of middle Miocene events (18-11.5 Ma) recognized (Van Niekerk et al., 1999; Beauvais et al, 2008; Gutzmer et al., 2012). On the other hand, the c. 10.5-11 Ma event matches a roughly simultaneous event documented for the Kalahari Manganese Field (Gutzmer et al., 2012), but not for West Africa. The rest of the Katanga paleosurface record is hardly comparable with records for other parts of Africa. The difference is most probably related to the specific regional geodynamic setting of the study area, which is influenced along its western and northern margins by Congo Basin dynamics and along its eastern border by the uplift of the East African Plateau and the opening of the EARS, from c. 25 Ma onward (Roberts et al., 2012). Such major tectonic events obviously prevail over the development of continent-wide paleosurfaces, and may also result in significant climate changes over large parts of Central Africa (Prömmel et al., 2013).

The present study provides a framework for the age of secondary ore deposits of the EARS region, both supergene and eluvial. These deposits include the major supergene $\mathrm{Cu}$-Co ores of the Copperbelt region, to which the results of a preliminary ${ }^{39} \mathrm{Ar}^{40}{ }^{40} \mathrm{Ar}$ study of the Kisenge deposits have already been applied (Decrée et al., 2010). Other examples are gold and tintantalum-tungsten eluvial deposits in the Great Lakes region, for which age information is still lacking, and the $\mathrm{Nb}-\mathrm{REE}$ deposit at Lueshe, Kivu, for which an undated supergene imprint has been identified (Nasraoui et al., 2000). This paper highlights the fact that the study of Cenozoic morphotectonic evolution of large parts of Central Africa, and its link with the formation of supergene ore deposits in this area, are still in relative infancy. 


\section{Acknowledgements}

This study is a contribution the Paleurafrica research project (BR/121/A3/Paleurafrica) of the Belgian Science Policy Office (BELSPO). C. Charlier (Service de Microscopie Electronique) is thanked for his help in using the SEM facility at the Université de Namur (Belgium). Dr M. Laghmouch (Royal Museum for Central Africa) has provided the DEM data and cartographic material used in this paper. Two anonymous reviewers are thanked for their constructive comments.

\section{References}

Alexandre J., 2002. Les cuirasses latéritiques et autres formations ferrugineuses tropicales Exemple du Haut-Katanga méridional. Annales du Musée Royal de l'Afrique Centrale, Sciences géologiques 107, 118p.

Anka, Z., Séranne, M., Lopez, M., Scheck-Wenderoth, M., Savoye, B., 2009. The long-term evolution of the Congo deep-sea fan: A basin-wide view of the interaction between a giant submarine fan and a mature passive margin (ZaiAngo project). Tectonophysics 470, 42-56.

Anka, Z., Séranne, M., di Primio, R., 2010. Evidence of a large upper Cretaceous depocentre across the Continent-Ocean boundary of the Congo-Angola basin. Implications for palaeodrainage and potential ultra-deep source rocks. Marine and Petroleum Geology 27, 301-611.

Beauvais, A., Chardon, D., 2013. Modes, tempo, and spatial variability of Cenozoic cratonic denudation: the West African example. Geochemistry, Geophysics, Geosystems 14, 15901608. 
Beauvais, A., Ruffet, G., Hénocque, O., Colin, F., 2008. Chemical and physical erosion rhythms of the West African Cenozoic morphogenesis: The ${ }^{39} \mathrm{Ar}-{ }^{40} \mathrm{Ar}$ dating of supergene $\mathrm{K}-$ Mn oxides. Journal of Geophysical Research 113, F04007, doi:10.1029/2008JF000996

Beugnies, A., 1954. La nappe phréatique des environs d'Élisabethville et les phénomènes connexes d'altération superficielle. Publications du Comité Spécial du Katanga (C.S.K.), série A, fascicule 3, Annales du Service des Mines et du Service Géographique et Géologique $17,3-54$.

Biagioni, C., Capalbo, C., Pasero M., 2013. Nomenclature tunings in the hollandite supergroup. European Journal of Mineralogy 25, 85-90.

Boni, M., Terracciano, R., Evans, N.J., Laukamp, C., Schneider, J., Bechstädt, T., 2007. Genesis of Vanadium Ores in the Otavi Mountainland, Namibia. Economic Geology 102, 441-469.

Bonnefille, R., 2010. Cenozoic vegetation, climate changes and hominid evolution in tropical Africa. Global and Planetary Change 72, 390-411.

Burke, K., Gunnell, Y., 2008. The African erosion surface: a continental-scale synthesis of geomorphology, tectonics, and environmental change over the past 180 million years. Geological Society of America, Memoir 201, 66p.

Butt, C.R.M, Bristow, A.P.J., 2012. Relief inversion in the geomorphological evolution of sub-Saharan West Africa. Geomorphology 185, 16-26.

Cahen, L., Snelling, N.J., 1984. The geochronology and evolution of Africa. Clarendon, Oxford, 512p. 
Cailteux, J.L.H., Kampunzu, A.B., Lerouge, C., Kaputo, A.K., Milesi, J.P., 2005. Genesis of sediment-hosted stratiform copper-cobalt deposits, Central African Copperbelt. Journal of African Earth Sciences 42, 134-158.

Chardon, D., Chevillotte, V., Beauvais, A., Grandin, G., Boulangé, B., 2006. Planation, bauxites and epeirogeny : one or two paleosurfaces on the West African margin? Geomorphology 82, 273-282.

Chisonga, B.C., Gutzmer, J., Beukes, N.K., Huizenga, J.M., 2012. Nature and origin of the protolith succession to the Paleoproterozoic Serra do Navio manganese deposit, Amapa Province, Brazil. Ore Geology Reviews 47, 59-76.

Colin, F., Beauvais, A., Ruffet, G., Hénocque, O., 2005. First ${ }^{39} \mathrm{Ar}^{-}{ }^{40} \mathrm{Ar}$ geochronology of lateritic manganiferous pisolites : implications for the Palaeogene history of a West African landscape. Earth and Planetary Science Letters 238, 172-188.

Decrée S., Deloule E., Ruffet G., Dewaele S., Mees F., Marignac C., Yans J., De Putter Th., 2010. Geodynamics and climate controls in the formation of Mio-Pliocene world-class oxidized cobalt and manganese ores in the Katanga province, DR Congo. Mineralium Deposita 45, 621-629.

Dewaele, S., Muchez, P., Vets, J., Fernandez-Alonzo, M., Tack, L., 2006. Multiphase origin of the $\mathrm{Cu}-\mathrm{Co}$ ore deposits in the western part of the Lufilian fold-and-thrust belt, Katanga (Democratic Republic of Congo). Journal of African Earth Sciences 46, 455-469.

De Dapper, M., 1991. Late Quaternary geomorphological evolution of the sand-covered plateaus near Kolwezi, Southern Shaba, Zaïre. Bulletin de la Société géographique de Liège $27,157-173$. 
De Putter Th., Mees F., Decrée S., Dewaele S., 2010. Malachite, an indicator of major Pliocene $\mathrm{Cu}$ remobilization in a karstic environment (Katanga, Democratic Republic of Congo). Ore Geology Reviews 38, 90-100.

Dill, H.G., Weber, B., Botz, R., 2013. Metalliferous duricrusts (“orecretes”) - markers of weathering: A mineralogical and climatic-geomorphological approach to supergene $\mathrm{Pb}-\mathrm{Zn}$ $\mathrm{Cu}-\mathrm{Sb}-\mathrm{P}$ mineralization on different parent materials. Neues Jahrbuch für Mineralogie Abhandlungen 190, 123-195.

Doyen, L., 1974. Etude métallogénique des gisements de manganèse de Kisenge - Kamata Kapolo. Unpubl. PhD thesis Brussels University, 493p.

Ebinger, C.J., Yemane, T., Woldegabriel, G., Aronson, J.L., Walter, R.C., 1993. Late Eocene-Recent volcanism and faulting in the southern main Ethiopian rift. Journal of the Geological Society 150, 99-108.

Fernandez-Alonso, M., Cutten, H., De Waele, B., Tack, L., Tahon, A., Baudet, D., Barritt, S.D., 2012. The Mesoproterozoic Karagwe-Ankole Belt (formerly the NE Kibara Belt): The result of prolonged extensional intracratonic basin development punctuated by two shortlived far-field compressional events. Precambrian Research 216-219, 63- 86.

Gasse, F., 2006. Climate and hydrological changes in tropical Africa during the past million years. Comptes-Rendus Palevol 5, 35-43.

Goudie, A.S., 2005. The drainage of Africa since the Cretaceous. Geomorphology 67, 437456.

Guillocheau, F., Chelalou, R., Linol, B., Dauteuil, O., Robin, C., Mvondo, F., Callec, Y., Colin, J.-P., 2015. Cenozoic landscape evolution in and around the Congo Basin : constraints 
from sediments and planation surfaces. In M.J. de Wit, F. Guillocheau, M.C.J. de Wit (eds), Geology and resource potential of the Congo Basin, 271-314.

Gutzmer, J., Du Plooy, A.P., Beukes, N.J., 2012. Timing of supergene enrichment of lowgrade sedimentary manganese ores in the Kalahari Manganese Field, South Africa. Ore Geology Reviews 47, 136-153.

Hanes, J.A., York, D., Hall, C.M., 1985. An ${ }^{40} \mathrm{Ar} /{ }^{39} \mathrm{Ar}$ geochronological and electron microprobe investigation of an Archean pyroxenite and its bearing on ancient atmospheric compositions. Canadian Journal of Earth Science 22, 947-958.

Hénocque, O., Ruffet, G., Colin, F., Féraud, G., 1998. ${ }^{40} \mathrm{Ar} /{ }^{39} \mathrm{Ar}$ dating of West African lateritic cryptomelanes. Geochimica et Cosmochimica Acta 62(16), 2739-2756.

Hitzman, M.W., Broughton, D., Selley, D., Woodhead, J., Wood, D., Bull, S., 2012. The Central African Copperbelt: diverse stratigraphic, structural, and temporal settings in the world's largest sedimentary copper district. Society of Economic Geologists, Special Publication 16, 487-514.

Kipata, M.L., Delvaux, D., Sebagenzi, M.N., Cailteux, J., Sintubin, M., 2013. Brittle tectonic and stress field evolution in the Pan-African Lufilian arc and its foreland (Katanga, DRC): from orogenic compression to extensional collapse, transpressional inversion and transition to rifting. Geologica Belgica 16, 1-17.

Kuleshov, V.N., 2011. Manganese Deposits: Communication 2. Major epochs and phases of manganese accumulation in the Earth's history. Lithology and Mineral Resources 46, 546565.

Lavier, L.L., Steckler, M.S., Brigaud, F., 2001. Climatic and tectonic control on the Cenozoic evolution of the West African margin. Marine Geology 178, 63-80. 
Ledent, D., Lay, C. Delhal, J., 1962. Premières données sur l'âge absolu des formations anciennes du « socle du Kasaï » (Congo méridional). Bulletin de la Société belge de Géologie, XXI, 223-235.

Lepersonne, J.,1974. Carte géologique du Zaïre. Musée Royal de l'Afrique Centrale, Tervuren.

Linol, B., de Wit, M.J., Guillocheau, F., Robin, C., Dauteuil, O., 2015a. Multiphase Phanerozoic subsidence and uplift history recorded in the Congo Basin : a complex successor basin. In M.J. de Wit et al. (eds), Geology and resource potential of the Congo Basin. Regional Geology Reviews, 213-227.

Linol, B., de Wit, M.J., Guillocheau, F., de Wit, M.C.J., Anka, Z., Colin, J.-P., 2015b. Formation and collapse of the Kalahari duricrust ['African Surface'] across the Congo Basin, with implications for changes in rates of Cenozoic off-shore sedimentation. In M.J. de Wit et al. (eds), Geology and resource potential of the Congo Basin. Regional Geology Reviews, 193-210.

Lippolt, H.J., Hautmann, S., $1995 .{ }^{40} \mathrm{Ar} /{ }^{39} \mathrm{Ar}$ ages of Precambrian manganese ore minerals from Sweden, India and Morocco, Mineralium Deposita 30, 246-256.

Marchandise, H., 1958. Le gisement et les minerais de manganèse de Kisenge (Congo belge). Bulletin de la Société Belge de Géologie, 67 : 187-210.

Mees, F., De Putter, Th., Decrée, S., Dewaele, S., 2012. Petrographical features of malachite from Katanga as indicators of mineral formation processes - preliminary results. In: S. Decrée, Th. De Putter (eds), Le secteur minier de la République démocratique du Congo à la croisée des chemins. Royal Museum for Central Africa, Tervuren, p. 73-74. 
Nasraoui, M., Toulkeridis, T., Clauer, N., Bilal, E., 2000. Differentiated hydrothermal and meteoric alterations of the Lueshe carbonatite complex (Democratic Republic of Congo) identified by a REE study combined with a sequential acid-leaching experiment. Chemical Geology 165, 109-132.

Nyame, F.K., 2008. Petrography and geochemistry of intraclastic manganese-carbonates from the $\sim 2.2$ Ga Nsuta deposit of Ghana: significance for manganese sedimentation in the Paleoproterozoic of West Africa. Journal of African Earth Sciences 50, 133-147.

Pack, A., Gutzmer, J., Beukes, N.J., van Niekerk, H.S., Hoernes, S., 2000. Supergene ferromanganese wad deposits derived from Permian Karoo strata along the Late CretaceousMid-Tertiary African land surface, Ryedale, South Africa. Economic Geology 95, 203-220.

Pasteels, P., Villeneuve, M., De Paepe, P., Klerkx, J., 1989. Timing of the volcanism of the southern Kivu Province: implications for the evolution of the western branch of the East African Rift system. Earth and Planetary Science Letters 94, 353-363.

Peters, C.R., O’Brien, E., 1999. Palaeo-lake Congo: implications for Africa's late Cenozoic climate - some unanswered questions. Proceedings of the $\mathrm{XV}^{\text {th }}$ INQUA Conference, Durban, South Africa, 3-11 August 1999. Palaeoecology of Africa and Surrounding islands 27, 11-18.

Pik, R., Marty, B., Carignan, J., Yirgu, G., Ayalew, T., 2008. Timing of East African Rift development in Southern Ethiopia: implication for mantle plume activity and evolution of topography. Geology 36 (2), 167-170.

Polinard, E., 1932. Esquisse géologique de la région située au sud du parallèle de SandoaKafakumba. Annales de la Société Géologique de Belgique 54, 100-105. 
Prömmel, K., Cubasch, U., Kaspar, F., 2013. A regional climate model study of the impact of tectonic and orbital forcing on African precipitation and vegetation. Palaeogeography, Palaeoclimatology, Palaeoecology 369, 154-162.

Renne, P.R., Balco, G., Ludwig, R.L., Mundil, R., Min, K., 2011. Response to the comment by W.H. Schwarz et al. on "Joint determination of ${ }^{40} \mathrm{~K}$ decay constants and ${ }^{40} \mathrm{Ar} * /^{40} \mathrm{~K}$ for the Fish Canyon sanidine standard, and improved accuracy for ${ }^{40} \mathrm{Ar} /{ }^{39} \mathrm{Ar}$ geochronology" by PR Renne et al. (2010). Geochimica et Cosmochimica Acta 75, 5097-5100.

Renne, P.R., Mundil, R., Balco, G., Min, K., Ludwi, R.L., 2011. Joint determination of ${ }^{40} \mathrm{~K}$ decay constants and ${ }^{40} \mathrm{Ar} * /{ }^{40} \mathrm{~K}$ for the Fish Canyon sanidine standard, and improved accuracy for ${ }^{40} \mathrm{Ar} /{ }^{39} \mathrm{Ar}$ geochronology. Geochimica et Cosmochimica Acta 74, 5349-5367.

Renne, P. R., Swisher, C. C., Deino, A. L., Karner, D. B., Owens, T. L., DePaolo, D. J., 1998. Intercalibration of standards, absolute ages and uncertainties in ${ }^{40} \mathrm{Ar} /{ }^{39} \mathrm{Ar}$ dating. Chemical Geology 145, 117-152.

Roberts, E.M., Stevens, N.J., O’Connor, P.M., Dirks, P.H.G.M., Gottfried, M.D., Clyde, W.C., Armstrong, R.A., Kemp, A.I.S., Hemming, S., 2012. Initiation of the western branch of the East African Rift coeval with the eastern branch. Nature Geoscience 5, 289-294.

Roddick, J. C., Cliff, R. A., ,Rex D. C., 1980. The evolution of excess argon in alpine biotites - $\mathrm{A}^{40} \mathrm{Ar}-{ }^{39} \mathrm{Ar}$ analysis. Earth Planetary Science Letters 48, 185-208.

Roy, S., 2006. Sedimentary manganese metallogenesis in response to the evolution of the Earth system. Earth-Science Reviews 77, 273-305.

Ruffet, G., Féraud, G., Amouric, M., 1991. Comparison of ${ }^{40} \mathrm{Ar} /{ }^{39} \mathrm{Ar}$ conventional and laser dating of biotites fram the North Trégor Batholith. Geochimica et Cosmochimica Acta 55, $1675-1688$. 
Ruffet, G., Féraud, G., Ballèvre, M., Kiénast, J.R., , 1995. Plateau ages and excess argon on phengites: ${ }^{40} \mathrm{Ar} /{ }^{39} \mathrm{Ar}$ laser probe study of alpine micas (Sesia zone). Chemical Geology 121 , $327-343$.

Ruffet, G., Innocent, C., Michard, A., Féraud, G., Beauvais, A., Nahon, D., Hamelin, B., 1996. A geochronological ${ }^{40} \mathrm{Ar} /{ }^{39} \mathrm{Ar}$ and ${ }^{87} \mathrm{Rb} /{ }^{87} \mathrm{Sr}$ study of K-Mn oxides from the weathering sequence of Azul, Brazil. Geochimica et Cosmochimica Acta 60, 2219-2232.

Schneiderhan, E.A., Gutzmer, J., Strauss, H., Mezger, K., Beukes, N.J., 2006. The chemostratigraphy of a Paleoproterozoic MnF-BIF succession - the Voëlwater Subgroup of the Transvaal Supergroup in Griqualand West, South Africa. South African Journal of Geology 109, 63-80.

Schuiling, H., Grosemans, P., 1956. Les gisements de manganèse du Congo belge. Congrès Géologique International, XXe session. Symposium sobre yacimientos de manganesos, II, Africa : 131-142.

Senut, B., Pickford, M., Ségalen, L., 2009. Neogene desertification of Africa. ComptesRendus Géosciences 341, 591-602.

Tardy, Y., Kobilsek, B., Paquet, H., 1991. Mineralogical composition and geographical distribution of African and Brazilian periatlantic laterites. The influence of continental drift and tropical paleoclimates during the past 150 million years and implications for India and Australia. Journal of African Earth Sciences 12, 283-295.

Tardy, Y., Roquin, C., 1998. Dérive des continents, Paléoclimats et altérations tropicales. BRGM, 473p.

Turner, G., 1971. ${ }^{40} \mathrm{Ar}^{-39} \mathrm{Ar}$ ages from the lunar Maria. Earth Planetary Science Letters 11, 169-191. 
USGS, 2009. Cobalt. Mineral Commodity Summaries, 195.

van Niekerk, H.S., Gutzmer, J., Beukes, N.J., Philips, D., Kiviets, G.B., 1999. An ${ }^{40} \mathrm{Ar} /{ }^{39} \mathrm{Ar}$ age of supergene K-Mn oxyhydroxides in a post-Gondwana soil profile on the Highveld of South Africa. South African Journal of Science 95, 450-454.

Vasconcelos, P.M., 1999. K-Ar and ${ }^{40} \mathrm{Ar}-{ }^{39} \mathrm{Ar}$ geochronology of weathering processes. Annual Review of Earth and Planetary Sciences 27, 183-229.

Vasconcelos P.M., T.A. Becker, P.R. Renne, Brimhall G.H., 1992. Age and duration of weathering by ${ }^{40} \mathrm{~K}-{ }^{40} \mathrm{Ar}$ and ${ }^{40} \mathrm{Ar} /{ }^{39} \mathrm{Ar}$ analysis of Potassium-Manganese Oxides, Science 58, 451-455.

Vasconcelos P.M., P.R. Renne, T.A. Becker, Wenk, H.R., 1995. Mechanisms and kinetics of atmospheric, radiogenic, and nucleogenic argon release from cryptomelane during ${ }^{40} \mathrm{Ar} /{ }^{39} \mathrm{Ar}$ analysis, Geochimica Cosmochimica Acta 59 (10), 2057-2070.

Vasconcelos P.M., P.R. Renne, G.H. Brimhall, Becker, T.A., 1994. Direct dating of weathering phenomena by ${ }^{40} \mathrm{Ar} /{ }^{39} \mathrm{Ar}$ and $\mathrm{K}-\mathrm{Ar}$ analysis of supergene $\mathrm{K}-\mathrm{Mn}$ oxides, Geochimica Cosmochimica Acta 58, 1635-1665.

Vasconcelos, P.M., Conroy, M., 2003. Geochronology of weathering and landscape evolution, Dugald River valley, NW Queensland, Australia. Geochimica et Cosmochimica Acta 67, 2913-2930.

Wichura, H., Bousquet, R., Oberhänsli, R., Strecker, M.R., Trauth, M.H., 2010. Evidence for middle Miocene uplift of the East African Plateau. Geology 38, 543-546. 


\section{Figure captions}

Fig. 1: A. Location map of the Kisenge deposit (green star), in western Katanga (Democratic Republic of the Congo), showing all major morphotectonic units mentioned in the paper and used in Figure 3. B. Geological map of the study area (after Lepersonne, 1974); C.

Topographic map of the study area derived from Shuttle Radar Topographic Mission (SRTM) digital elevation model (DEM).

Fig. 2: Schematic log of the Kis-1 profile, and of some other boreholes crossing the Kisenge deposit (after Doyen, 1974); bedding is shown in grey shaded surfaces on the basis of dip measurements. The dotted line (A) emphasizes the probable continuity between the bedding and the position of the unweathered carbonate ore and garnetite level in the Kis-1 core. The material studied in this paper comes from the Kis-1 core only.

Fig. 3: Overview of uplift and other major geodynamic events in the Congo Basin, Katanga, the East African Rift System (EARS) and East African Plateau (EAP) during the Cenozoic, with indications of supergene mineral deposits formed during this $45 \mathrm{My}$ interval. Horizontal dashed grey lines suggest possible correlations between events occurring in different morphotectonic areas. The Mio-Pliocene interval in Katanga is further detailed in Figure 9.

Fig. 4: Backscattered electron images and SEM-EDS maps for selected samples. (A) RGM 13933, and (B) Kis-1/62 showing chemically relatively homogeneous zones; (C) Kis-1/36 displaying cryptomelane laminae with a minor Al-rich lithiophorite phase, confirmed by XRD analysis.

Fig. 5: Pictures of selected studied samples: A to D are surface samples, E and F are taken from the Kis-1 core. Inserts show the analysed and dated fragment (on a millimetre-sized 
grid). Sample identification: $A=R G M$ 1769; $B=R G M$ 13200; $C=R G M$ 10727; $D=$ RGM 14296; $\mathrm{E}=$ Kis-1/30; $\mathrm{F}=$ Kis-1/53 (see Table 2 for description).

Fig. 6: ${ }^{39} \mathrm{Ar}-{ }^{40} \mathrm{Ar}$ age spectra of Mn oxide samples. Age spectra of samples of the Kis-1 core (Kis-1/30 to Kis-1/62) are grouped together for clarity, with indications of sampling depth. Apparent age error bars are at the $1 \sigma$ level; errors in the J-values are not included. Plateau and pseudo-plateau ages ( $1 \sigma$ uncertainties) are given when applicable. Frequency diagram of apparent ages (grey) and of pseudo-plateau and plateau ages (coloured) are shown bottom right. Identified phases are each indicated using a specific colour throughout the figure (these colours are also used in Figures 8 and 9): >19.2 Ma (red), c. 15.7 Ma (orange), c. 14.2 Ma (yellow), c. 13.6 Ma (purple), c. 10.5 Ma (blue), c. 3.6 Ma (dark green), c. 2.6 Ma (light green).

Fig. 7: Processing of results for sample RGM $10727 \mathrm{c}$ with three identified phases $\alpha, \beta$ and $\gamma$. A. Degassing diagram, presenting $\left({ }^{\mathrm{x}} \mathrm{Ar} / \Delta \mathrm{T}^{\circ}\right) /\left({ }^{\mathrm{x}} \mathrm{Ar} / \Delta \mathrm{T}^{\circ}\right)$ Max vs. $\%{ }^{39} \mathrm{Ar}_{\mathrm{K}}$, with $\mathrm{x}=40$ for ${ }^{40} \mathrm{Ar}{ }^{*}$ (grey) and $\mathrm{x}=36$ for ${ }^{36} \mathrm{Ar}$ (light blue), $\Delta \mathrm{T}^{\circ}$ corresponds to laser power increment; $\mathrm{B}$. Inverse isochron (correlation) diagram, with ${ }^{36} \mathrm{Ar} /{ }^{40} \mathrm{Ar}$ vs. ${ }^{39} \mathrm{Ar} /{ }^{40} \mathrm{Ar}$, ellipses without fill are excluded from isochron regression, MSWD stands for Mean Squares of Weighted Deviates; C. Conventional age spectrum (apparent ages vs. $\%{ }^{39} \mathrm{Ar}_{\mathrm{K}}$ ); D. Weighted age spectrum presenting apparent ages vs. $\%\left({ }^{39} \mathrm{Ar}_{\mathrm{K}} / \Delta \mathrm{T}^{\circ}\right) /\left({ }^{39} \mathrm{Ar}_{\mathrm{K}} / \Delta \mathrm{T}^{\circ}\right)_{\text {Max }}$; E. Photograph of sample grain RGM $10727 \mathrm{c}$ taken before fusion step, with banded structures visible at grain surface.

Fig. 8: Selection of some inverse isochron (correlation) diagrams, plotting ${ }^{36} \mathrm{Ar} /{ }^{40} \mathrm{Ar}$ vs. ${ }^{39} \mathrm{Ar} /{ }^{40} \mathrm{Ar}$; ellipses without fill are excluded from isochron regressions. MSWD stands for Mean Squares of Weighted Deviates.

Fig. 9: A. Shuttle Radar Topographic Mission (SRTM) digital elevation model (DEM) of the study area, with a topographic profile (orange line) from Kisenge (West) to Kolwezi (East); 
three plateaus are observed, at $\sim 1100 \mathrm{~m}$ a.s.1., $~ 1200 \mathrm{~m}$ and >1550 $\mathrm{m}$ a.s.1 (Copperbelt); B. Sketch of the three major cryptomelane formation phases (at 10.5, 3.6 and 2.6 Ma) with their respective extent within the Kis-1 core. Each phase is superimposed on the previous one(s). Colours for the three Mn oxide formation phases are also used in Figures 6 and 8. 


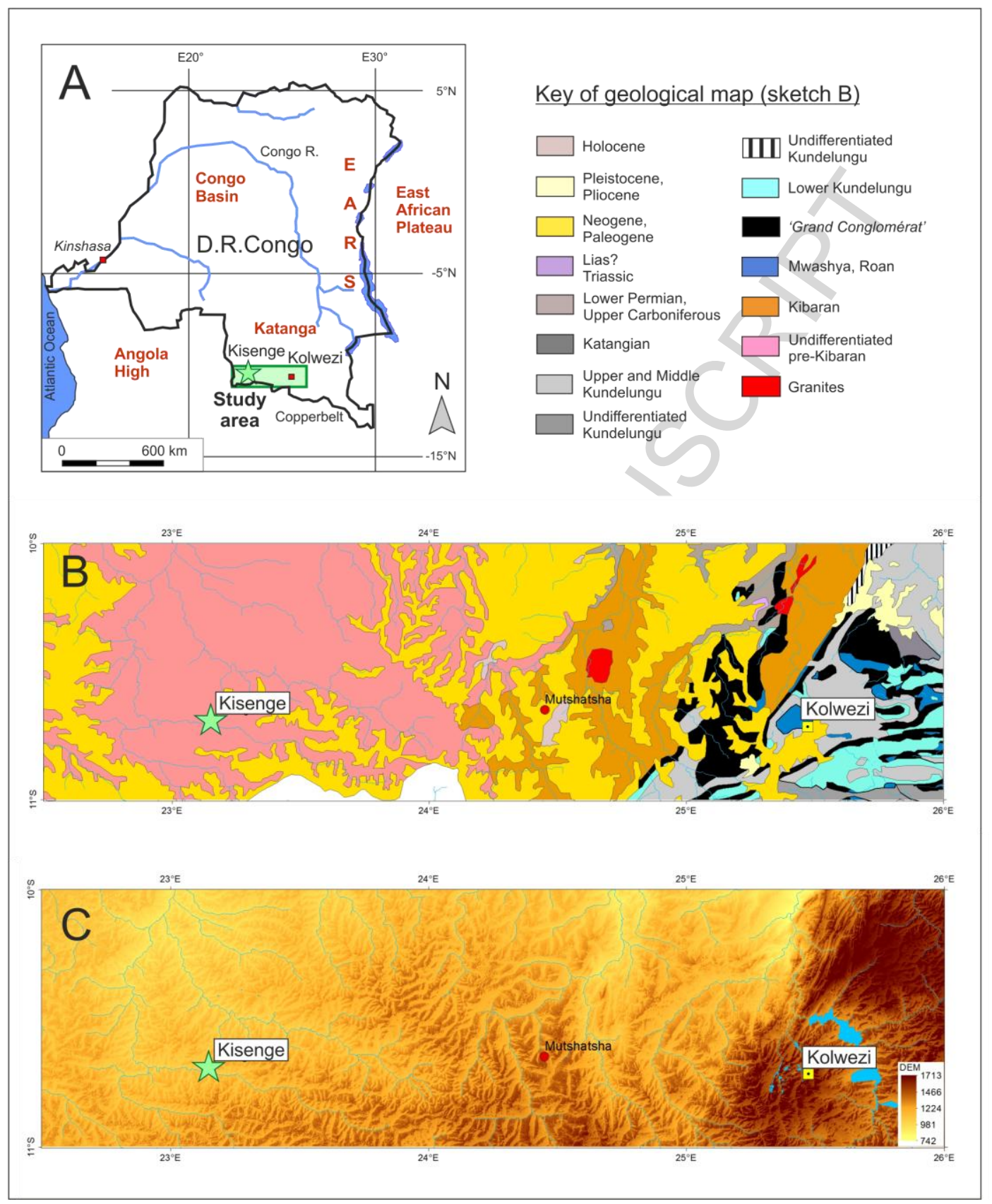

Figure 1 


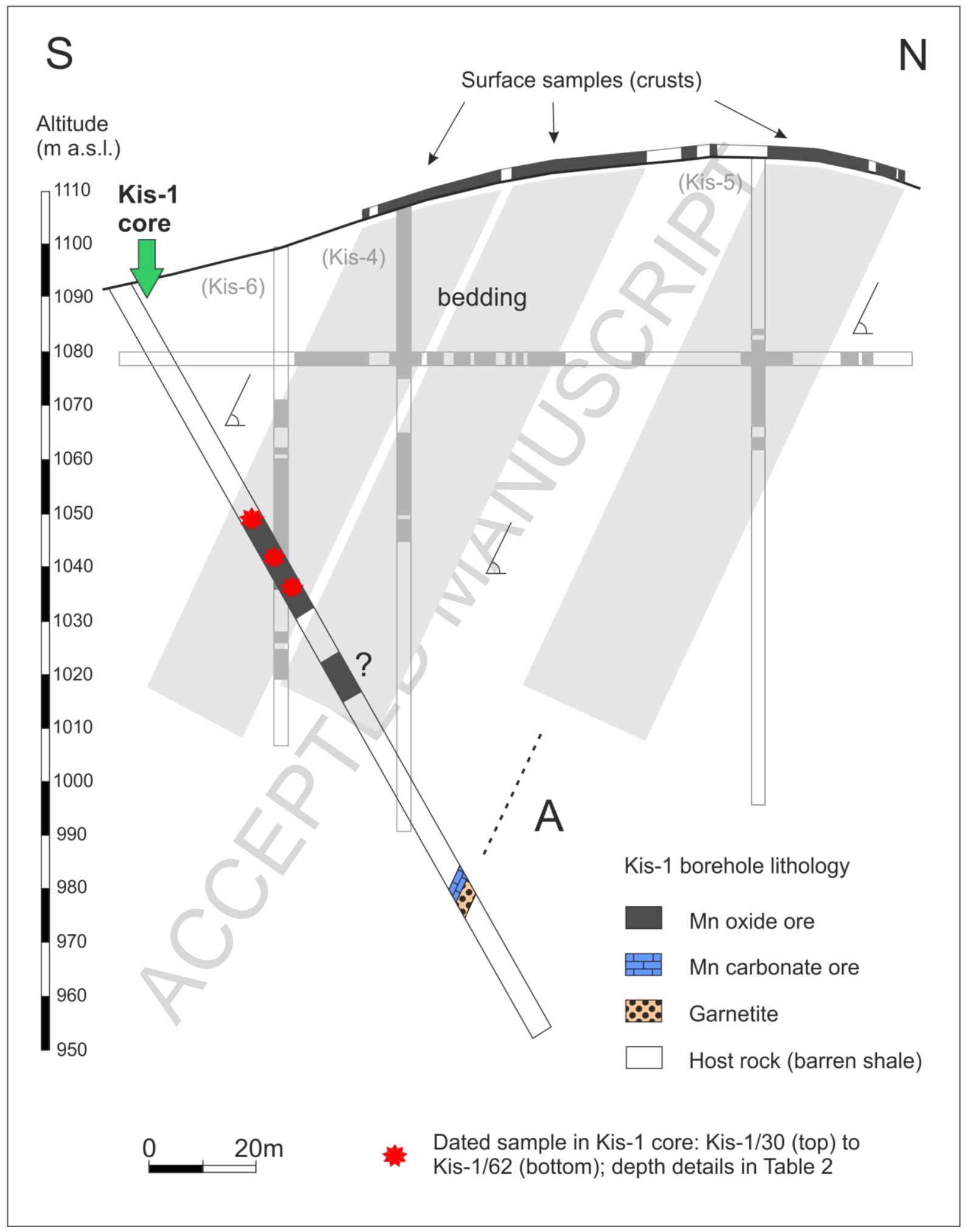

Figure 2 
Age (My) Congo B. Katanga EARS EAP Ore Deposits

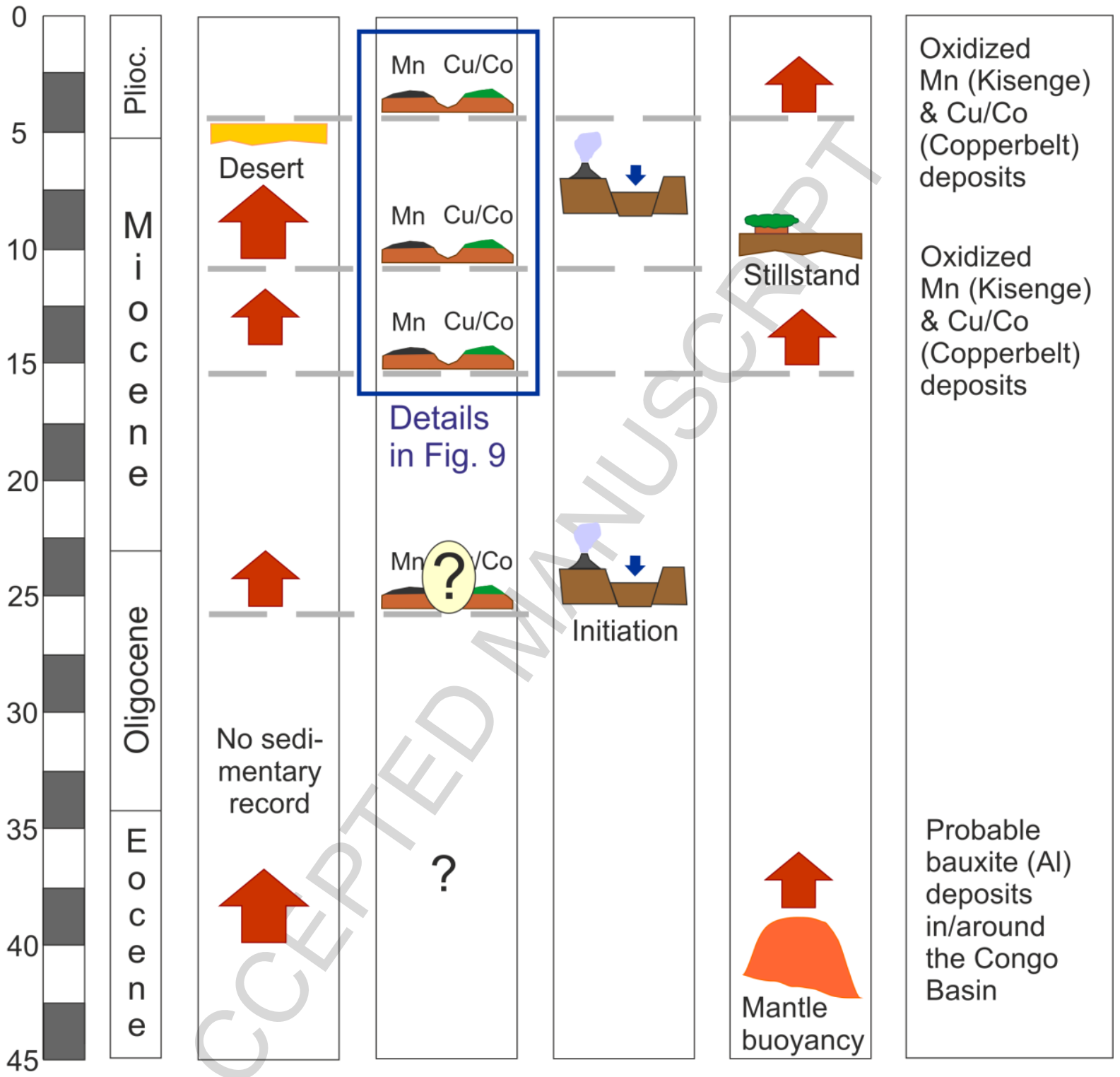

Figure 3 

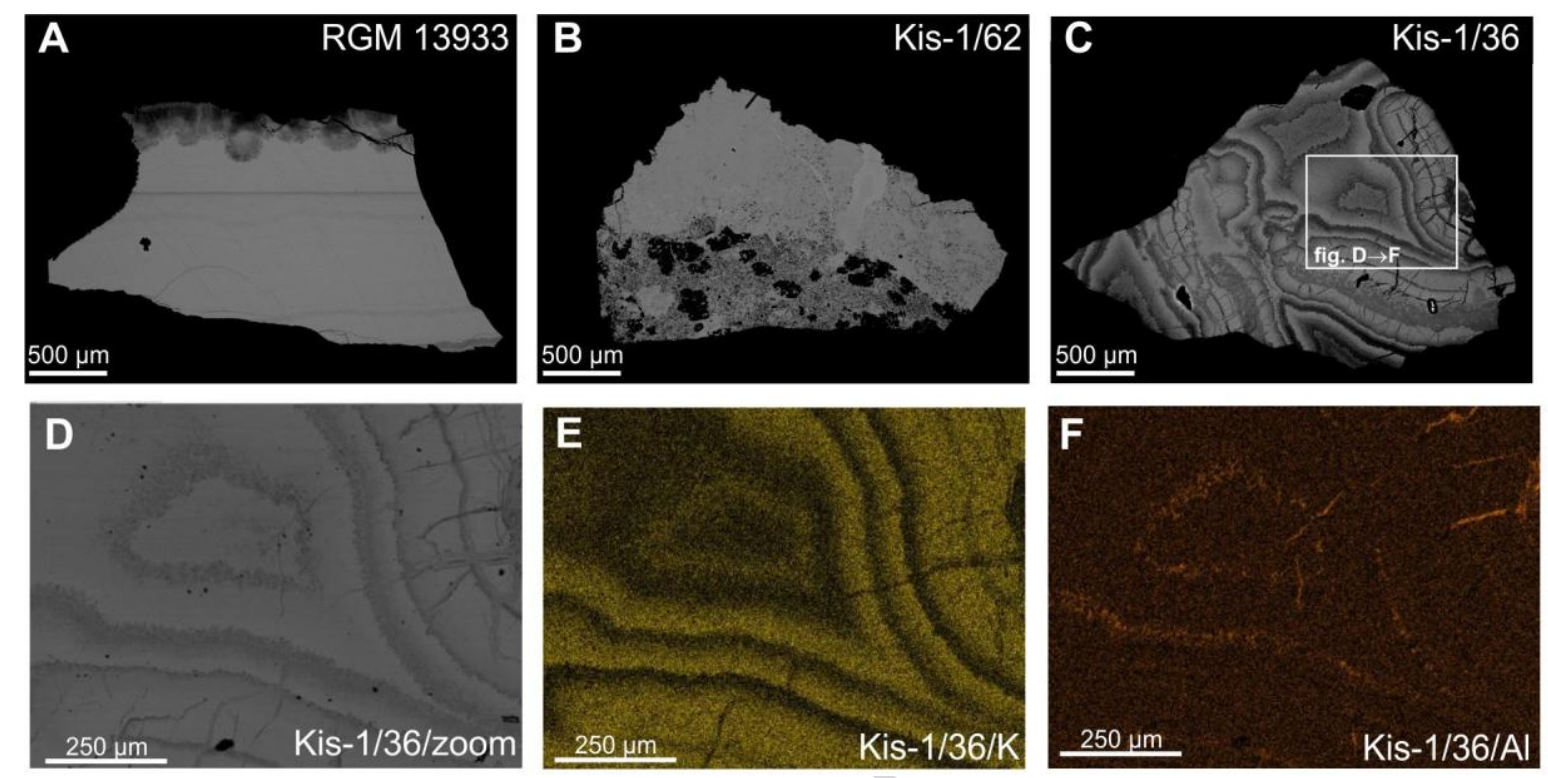

Figure 4 


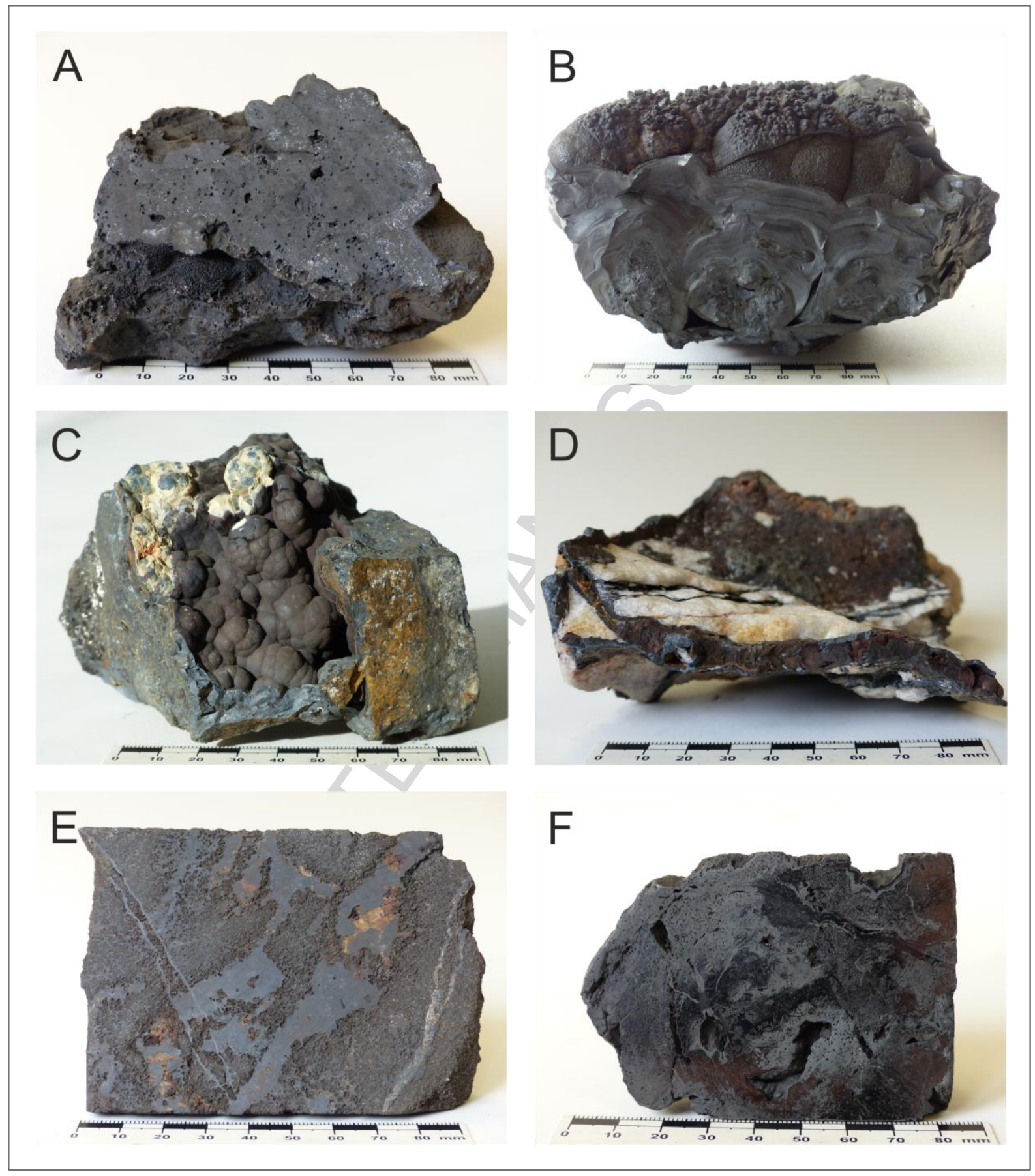

Figure 5 


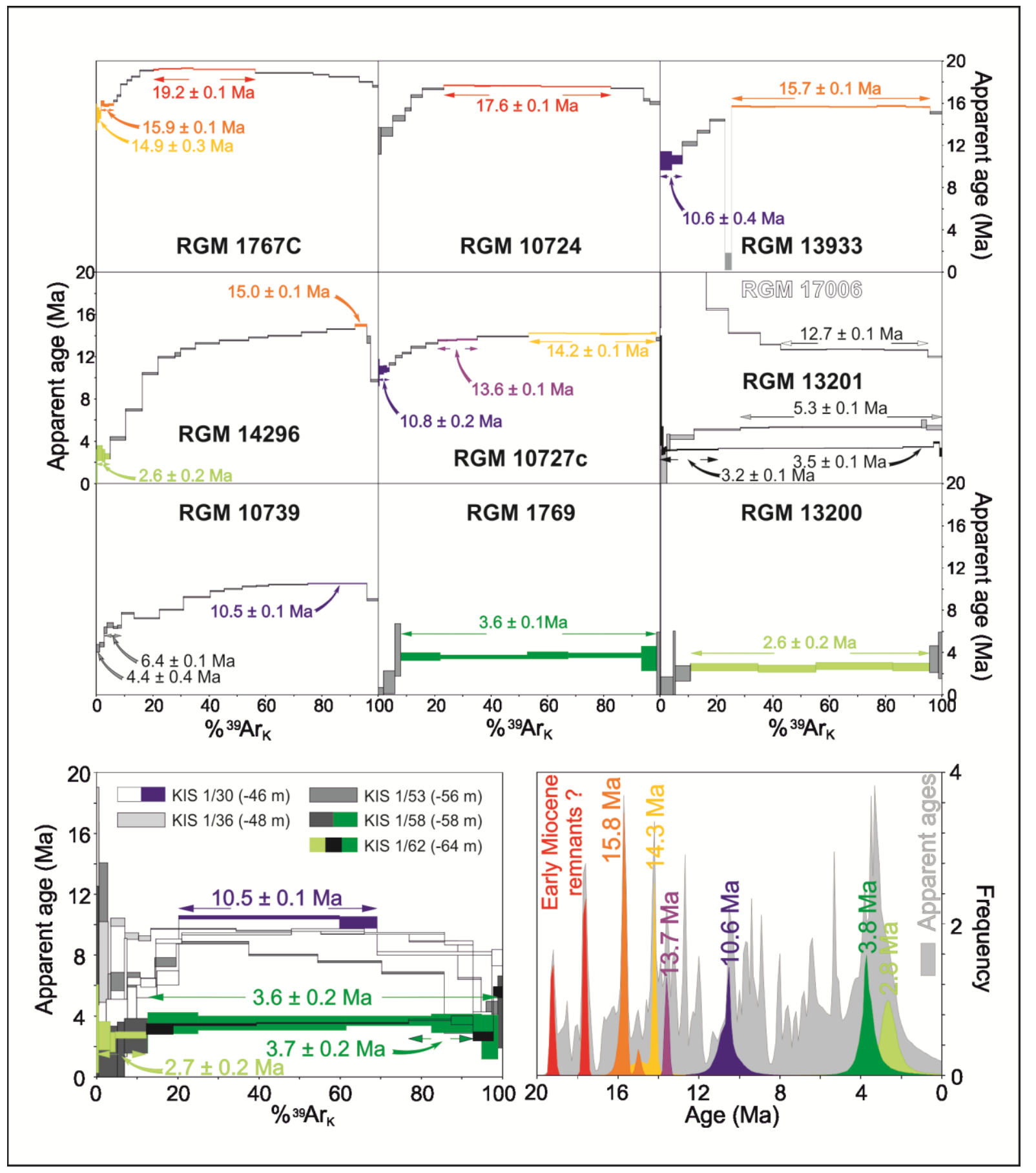

Figure 6 


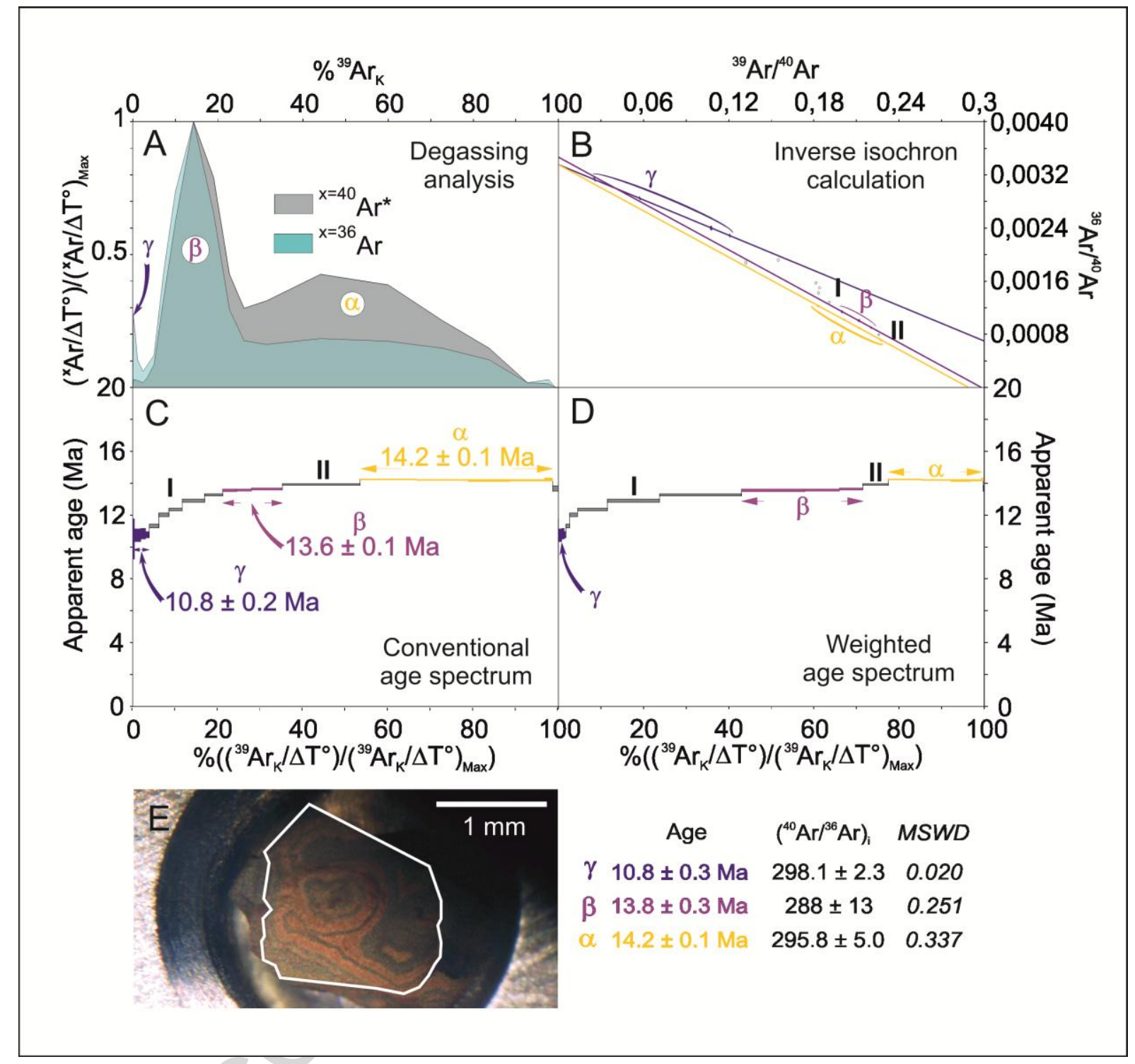

Figure 7 


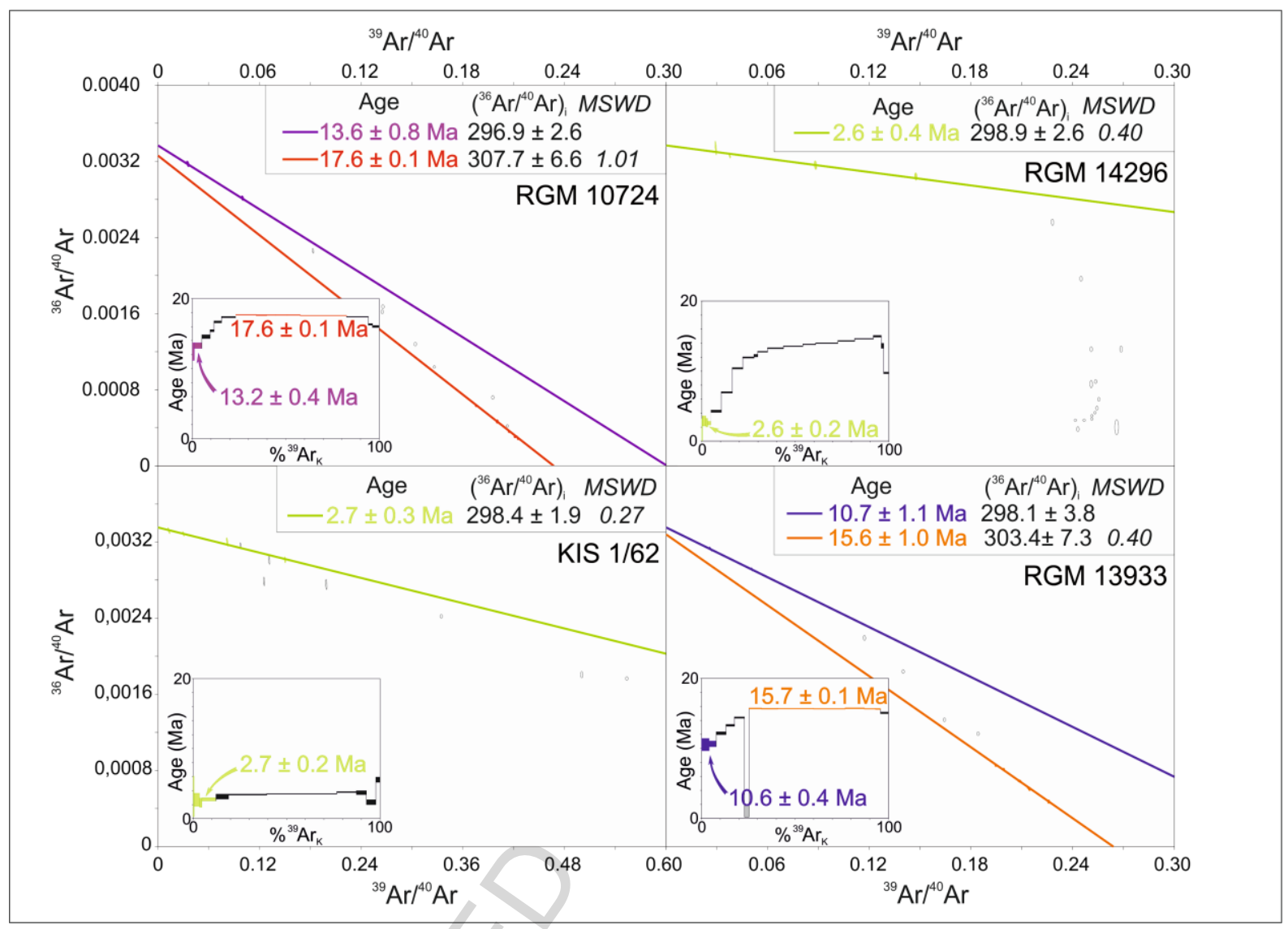

Figure 8 


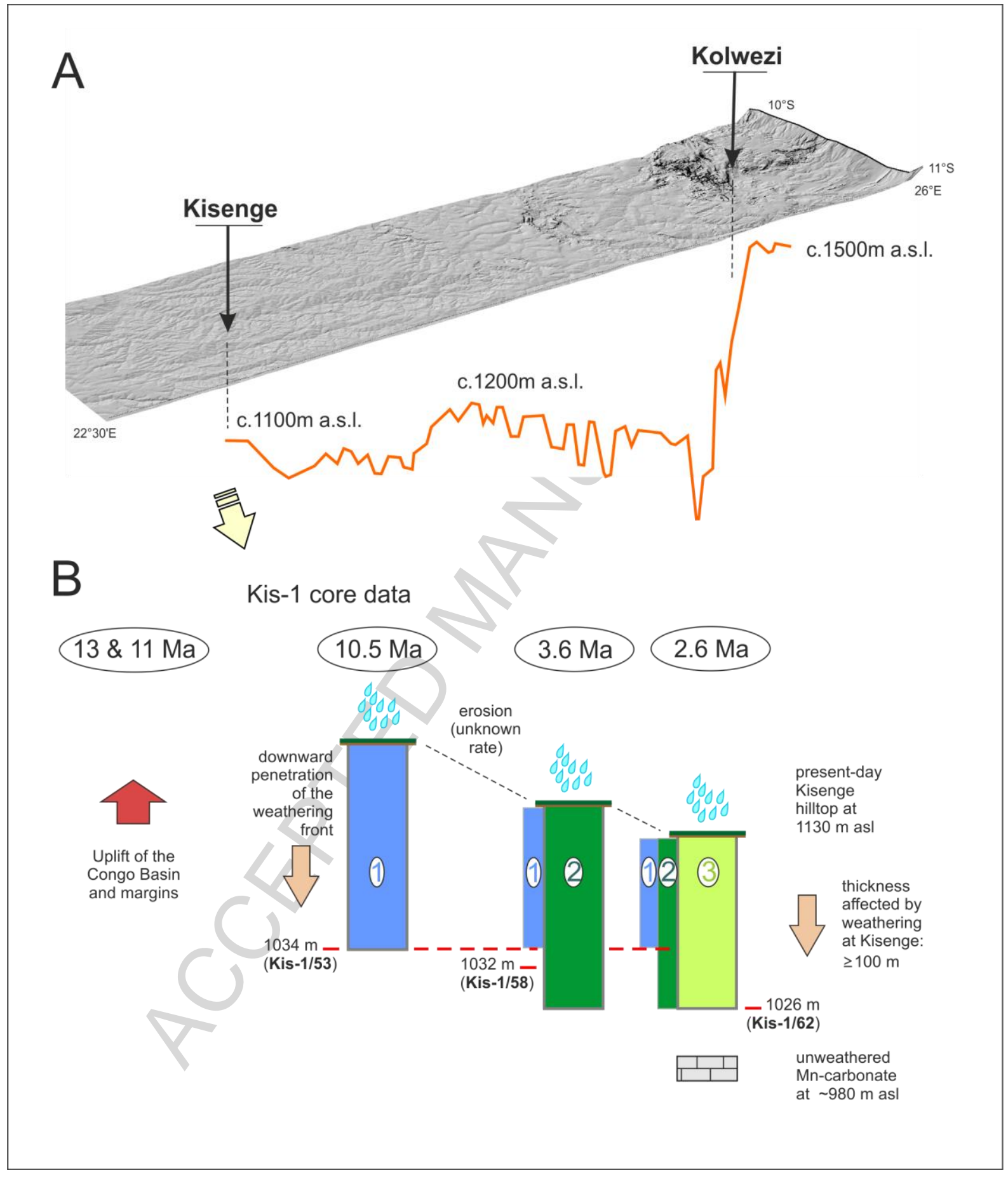

Figure 9 
Table 1: Overview of age information on Cenozoic supergene manganese (Mn) and vanadium (V) ores deposits in western, central and southern Africa

\begin{tabular}{|c|c|c|c|c|c|c|}
\hline Area & Type & Country & Deposit & Geologic context & $\begin{array}{l}\text { Radiometric } \\
\text { age }(\mathrm{Ma})\end{array}$ & References \\
\hline $\begin{array}{l}\text { West } \\
\text { Africa }\end{array}$ & $\mathrm{Mn}$ & $\begin{array}{l}\text { Burkina } \\
\text { Faso }\end{array}$ & Tambao & $\begin{array}{l}\text { Mn-laterite on primary } \\
\text { Proterozoic carbonate ore }\end{array}$ & $\begin{array}{l}\text { Ar-Ar age } \\
\text { clusters: } \\
-\quad 59-56 \\
-\quad 47-44 \\
-\quad 27-24\end{array}$ & $\begin{array}{l}\text { Colin et al. } \\
(2005) ; \\
\text { Beauvais et al. } \\
(2008)\end{array}$ \\
\hline $\begin{array}{l}\text { Central } \\
\text { Africa }\end{array}$ & $\mathrm{Mn}$ & D.R.Congo & Kisenge & $\begin{array}{l}\text { Mn-laterites on primary } \\
\text { Paleoproterozoic (?) Mn- } \\
\text { carbonate (rhodochrosite) } \\
\text { ore }\end{array}$ & $\begin{array}{ll}\text { Ar-Ar ages: } \\
-\quad>19 \\
-\quad 11-10.5 \\
-\quad 3.7-3.5 \\
-\quad 2.7-2.6 \\
\end{array}$ & $\begin{array}{l}\text { Decrée et al. } \\
(2010) ; \text { this } \\
\text { paper }\end{array}$ \\
\hline \multirow[t]{3}{*}{$\begin{array}{l}\text { Southern } \\
\text { Africa }\end{array}$} & $\mathrm{Mn}$ & N. RSA & $\begin{array}{l}\text { Kalahari } \\
\text { Manganese } \\
\text { Field }\end{array}$ & $\begin{array}{l}\text { Altered manganese ore on } \\
\text { primary Paleoproterozoic } \\
\text { braunite lutite }\end{array}$ & $\begin{array}{l}\text { Ar-Ar ages: } \\
-\quad 42 \text { (max.) } \\
-\quad 26.7 \\
-\quad 10.1 \\
-\quad 5.2\end{array}$ & $\begin{array}{l}\text { Van Niekerk et } \\
\text { al. (1999); } \\
\text { Gutzmer et al. } \\
(2012)\end{array}$ \\
\hline & Mn & N. RSA & & $\begin{array}{l}\text { Ferromanganese wad } \\
\text { infilling in sediments } \\
\text { trapped within Permian } \\
\text { karsts on Neoearchean } \\
\text { dolomite }\end{array}$ & $\begin{array}{l}\text { Ar-Ar ages: } \\
-\quad \text { ca. } 18-16\end{array}$ & $\begin{array}{l}\text { Pack et al. } \\
(2000)\end{array}$ \\
\hline & $\mathrm{V}$ & $\begin{array}{l}\text { N. } \\
\text { Namibia }\end{array}$ & $\begin{array}{l}\text { Otavi } \\
\text { Mountainland }\end{array}$ & $\begin{array}{l}\mathrm{Zn}-\mathrm{Cu}-\mathrm{Pb} \text { vanadate } \\
\text { infilling in Miocene (?) } \\
\text { karst depressions within } \\
\text { sulfide-bearing } \\
\text { Neoproterozoic Otavi } \\
\text { carbonate }\end{array}$ & 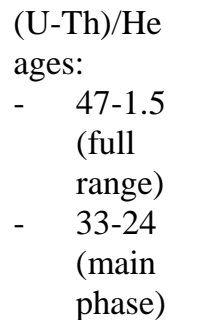 & $\begin{array}{l}\text { Boni et al. } \\
\text { (2007) }\end{array}$ \\
\hline
\end{tabular}


Table 2 : description of the analysed samples; depth along the core is given for the 5 core samples. The 'analysed feature' column is a description of the analysed and dated millimetric fragments, while the 'context' column describes the hand-size specimen whence the analysed sample was taken. The 'mould' character of spessartine is confirmed by the absence of this mineral in XRD patterns.

\begin{tabular}{|c|c|c|}
\hline Sample id & Analysed feature & Context \\
\hline \multicolumn{3}{|l|}{ core } \\
\hline $\begin{array}{l}\text { Kis-1/30 } \\
\text { (depth }-46 m)\end{array}$ & $\begin{array}{l}\text { irregular cryptomelane veins or layers (up } \\
\text { to } 2 \mathrm{~cm} \text { thick) with metallic lustre }\end{array}$ & $\begin{array}{l}\text { dark porous } \mathrm{Fe} / \mathrm{Mn} \text {-oxide-rich matrix with spessartine crystal } \\
\text { moulds; the cryptomelane veins are crossed by generation of } \\
\text { thinner }(\mathrm{mm}) \text { Mn oxide veins }\end{array}$ \\
\hline $\begin{array}{l}\text { Kis- } 1 / 36 \\
\text { (depth }-48 m)\end{array}$ & $\begin{array}{l}\text { coalesced round cryptomelane aggregates } \\
\text { or nodules forming a cm-thick vein or } \\
\text { crust }\end{array}$ & $\begin{array}{l}\text { mm-thick laminar coating at the interface with the dark grey to } \\
\text { brownish porous substrate with abundant spessartine crystal } \\
\text { moulds; crossed by mm-thick Mn oxide veins }\end{array}$ \\
\hline $\begin{array}{l}\text { Kis- } 1 / 53 \\
\text { (depth }-56 \\
\text { m) }\end{array}$ & $\begin{array}{l}\text { porous cryptomelane mass with numerous } \\
\text { moulds of spessartine crystals, but with } \\
\text { some massive mould-free zones }\end{array}$ & coatings or mm-thick veins; large irregular pores (up to $3 \mathrm{~cm}$ ) \\
\hline $\begin{array}{l}\text { Kis- } 1 / 58 \\
\text { (depth }-58 \\
\text { m) }\end{array}$ & $\begin{array}{l}\text { coalesced round cryptomelane aggregates } \\
\text { (up to } 5 \mathrm{~mm} \text { diameter), with partially } \\
\text { concentric layering and metallic lustre }\end{array}$ & numerous inter-aggregate pores (up to $1 \mathrm{~cm}$ diameter) \\
\hline $\begin{array}{l}\text { Kis-1/62 } \\
\text { (depth }-64 \\
\text { m) }\end{array}$ & $\begin{array}{l}\text { coalesced round cryptomelane aggregates } \\
\text { (up to } 5 \mathrm{~mm} \text { diameter), with partially } \\
\text { concentric layering and metallic lustre }\end{array}$ & $\begin{array}{l}\text { dark dull cryptomelane matrix; sporadic large pores (up to } 3 \\
\mathrm{~cm} \text { long) }\end{array}$ \\
\hline \multicolumn{3}{|l|}{ surface } \\
\hline RGM 1767c & $\begin{array}{l}\text { cryptomelane crust (up to } 1 \mathrm{~cm} \text { thick) } \\
\text { with weakly expressed lamination and } \\
\text { metallic lustre }\end{array}$ & $\begin{array}{l}\text { black spessartine-rich stratified substrate; some accessory } \\
\text { lithiophorite; the crust crosses the stratification at high angle } \\
\text { range }\left(75^{\circ} \text { to } 90^{\circ}\right) \text {; }\end{array}$ \\
\hline RGM 1769 & $\begin{array}{l}\text { heterogeneous cryptomelane mass with } \\
\text { contrasting parts with metallic and dull } \\
\text { lustre, commonly finely laminated; } \\
\text { probable spessartine moulds and larger } \\
\text { pores (up to a few mm) }\end{array}$ & $\begin{array}{l}\text { botryoidal/mammillary surface, covered by layer }(1 \mathrm{~cm} \text { thick }) \\
\text { of prismatic crystals with a highly metallic lustre }\end{array}$ \\
\hline RGM 10724 & $\begin{array}{l}\text { botryoidal/mammillary cryptomelane } \\
\text { crust (up to } 3 \mathrm{~cm} \text { thick) with weakly } \\
\text { expressed lamination }\end{array}$ & dark dense spessartine crystal moulds-rich black substrate \\
\hline RGM $10727 \mathrm{c}$ & $\begin{array}{l}\text { complex botryoidal/mammillary } \\
\text { cryptomelane crust (up to } 1 \mathrm{~cm} \text { thick) } \\
\text { with clearly expressed laminated fabric }\end{array}$ & dark dense non-porous substrate \\
\hline RGM 10739 & $\begin{array}{l}\text { cryptomelane porous crust (up to } 4 \mathrm{~cm} \\
\text { thick), with overall } \\
\text { botryoidal/mammillary aspect, consisting } \\
\text { of at least three superimposed palisadic } \\
\text { layers of wide prismatic units with inter- } \\
\text { aggregate porosity }\end{array}$ & none \\
\hline RGM 13200 & dense laminated cryptomelane crust (up & base of the crust is irregular and contains fragments of the \\
\hline
\end{tabular}


to $6 \mathrm{~cm}$ thick) with metallic lustre, with complex botryoidal/mammillary surface

RGM 13201

cryptomelane crust (up to $3.5 \mathrm{~cm}$ thick), weakly to clearly laminated, covered by layer of parallel crystals (perpendicular to surface)

RGM 13933 cryptomelane crust (0.5 cm thick), with weakly expressed lamination, composed of parallel crystals (perpendicular to surface)

RGM 14296 cryptomelane vein (up to $1 \mathrm{~cm}$ thick), composed of weakly to strongly coalesced round aggregates, lined by symmetric thin $(\sim 0.1 \mathrm{~cm})$ dense Mn oxide layers

RGM 17006 complex botryoidal/mammillary cryptomelane crust (up to $1 \mathrm{~cm}$ thick) with prominent lamination underlying silty/clayey substrate

none

none

quartzite matrix at both sides of the vein

porous spessartine crystal moulds-rich substrate; visible intercalation of whitish silicates (confirmed with SEM-EDS) in outer part of the crust 


\section{Research highlights}

- First extensive Ar-Ar study of Mn ores in Central Africa

- Main age clusters around 10.5, 3.6 and 2.6 My for supergene ore development

- Katanga as a key area for Neogene evolution of Central Africa 